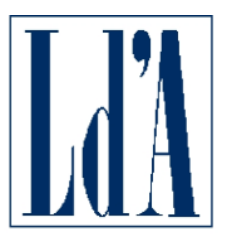

CENTRO STUDI LUCA D'AGLIANO

WWW.DAGLIANO.UNIMI.IT

\author{
CENTRO STUDI LUCA D'AGLIANO \\ DEVELOPMENT STUDIES WORKING PAPERS
}

N. 358

October 2013

Mind What Your Voters Read:

Media Exposure and International Economic Policy Making

Giovanni Facchini*

Tommaso Frattini**

Cora Signorotto***

* University of Nottingham, University of Milan, CEPR, CES-Ifo, CrEAM, IZA and Centro Studi Luca d'Agliano

** University of Milan, CrEAM, IZA and Centro Studi Luca d'Agliano *** University of Milan and Centro Studi Luca d'Agliano 


\title{
Mind what your voters read: Media exposure and international economic policy making*
}

\author{
Giovanni Facchini† Tommaso Frattini ${ }^{\ddagger}$ and Cora Signorotto ${ }^{\S}$
}

October 13, 2013

\begin{abstract}
We investigate the role of constituents' preferences in shaping the voting behavior of elected representatives on immigration and trade policy. Using a novel dataset spanning the period 1986-2004, in which we match individual opinion surveys with congressmen roll call votes, we find that greater exposure to media coverage tends to increase a politician's accountability when it comes to migration policy making, while we find no effect for trade policy. Our results thus suggest that more information on the behavior of elected officials affects decisions only when the policy issue is perceived to be salient by the electorate.

JEL classification: F22, J61.

Keywords: Trade Reforms, Immigration Reforms, Individual preferences, Media exposure.
\end{abstract}

${ }^{*}$ This paper is produced as part of the project Temporary Migration, Integration and the role of Policies (TEMPO) funded by the NORFACE Research Programme: Migration in Europe - Social, Economic, Cultural and Policy Dynamics.

†University of Nottingham, Universitá degli Studi di Milano, CEPR, CES-Ifo, CrEAM, IZA and LdA; giovanni.facchini@nottingham.ac.uk.

†Universitá degli Studi di Milano, CrEAM, IZA, LdA; email: tommaso.frattini@unimi.it.

§Universitá degli Studi di Milano, LdA; email: cora.signorotto@unimi.it. 


\section{Introduction}

Liberalizing trade and migration policies brings about efficiency gains, that have been documented in several studies, using a variety of theoretical frameworks (e.g. see Hamilton and Whalley 1984, Feenstra 1995, di Giovanni, Levchenko, and Ortega 2012, Arkolakis, Costinot, and Clare 2012). Still, as argued by many observers, important distortions continue to exist to the international flow of both goods and workers, and a distinguished literature has developed over the years to understand why and how these distortions are put in place. As argued by Rodrik (1995), the starting block of all these analyses is represented by individual preferences towards globalization. While several studies have analyzed the drivers of attitudes towards globalization, little direct evidence exists on the process through which they are taken into account in the actual policy making. The goal of this paper is to address this important question by looking at support for both immigration and trade reform.

Our analysis will focus on the United States, a country for which we have been able to gather information on the preferences of the electorate on these two issues, and for which we also have data on the decisions taken by elected officials. In particular, we have constructed measures of aggregate opinion towards trade and migration at the congressional district level, and combined that information with data on the voting behavior of each congressman on trade and migration policy, together with a wealth of additional district and individual policy maker information. Our data cover two decades spanning the period 1986-2004 during which Congress acted on several key pieces of legislation, like the 1993 approval of the North American Free Trade Agreement, the 1994 ratification of the Uruguay Round Agreements of the GATT and the 1996 Illegal Immigration Reform and Immigrant Responsibility Act.

As argued by several scholars in economics and political science, knowledge of the behavior of elected representatives is key to insure their accountability to the electorate. ${ }^{1}$ For this reason, in our analysis we use media, to capture the information available to her constituents. Our proxy builds on previous work by Snyder and Strömberg (2010) who have convincingly argued that the geographic mismatch between the market for local newspapers and the shape of the congressional district provides useful insights on the actual information that is exogenously available to the individual constituent.

Our analysis suggests that important differences exist between the mechanisms through which

\footnotetext{
${ }^{1}$ This point was already made by the founding fathers of the US Constitution. Thomas Jefferson already suggested that "... the functionaries of every government have propensities to command at will the liberty and property of their constituents. There is no safe deposit for these, but with the people themselves, nor can they be safe with them without information. Where the press is free, and every man able to read, all is safe." Thomas Jefferson to Charles Yancey, January 6, 1816. Thomas Jefferson Papers Series 1, General Correspondence, 16511827, Library of Congress, American Memory, http://memory.loc.gov/.
} 
preferences towards international trade and migration inform the actual policy making. In particular, we find that greater exposure to the scrutiny exercised by the media has a statistically significant and sizeable disciplining effect when it comes to migration policy. The same is instead not true when we consider international trade. This basic result continues to hold when we control for a variety of additional district and individual level characteristics that have been found in the previous literature to be important drivers of representative's voting behavior in international economic policy making.

How can these findings be rationalized? Standard economic models in the tradition of Heckscher and Ohlin suggest that trade and migration share similar causes and have analogous consequences when it comes to the labor market position of workers in the destination country. At the same time, it is well known that there are important differences between the drivers of preferences towards trade and migration. For instance, welfare state considerations are likely to play a much bigger role for the latter rather than the former, and the same is true when it comes to cultural factors (Hanson, Scheve, and Slaughter 2007). As a result, while in many opinion surveys immigration appears as one of the most important issues facing the individual respondent, this is hardly the case for trade policy. For example, data from the Cooperative Congressional Election Study highlight that in 2006 over $40 \%$ of the respondents in the United States thought that migration was an extremely important issue in determining whom they voted for, suggesting that this issue is as relevant as social security, taxes and education. Trade, on the other hand, was rated at the same level of salience only by $16 \%$ of the respondents (see Guisinger 2009). One possible explanation for our findings is thus that media exposure enhances accountability only for issues which are perceived to be salient by the electorate.

The remainder of the paper is organized as follows. Section 2 relates our work to the existing literature, whereas section 3 presents the measure of media exposure. Section 4 discusses our main results. Section 6 assesses the robustness of our findings, while section 7 concludes the paper.

\section{Literature}

The analysis carried out in this paper contributes to fill an important gap in the literature by directly exploring the link between individual preferences towards globalization and the voting behavior of U.S. representatives on trade and migration policy reforms. In particular, our focus is on the role of the media in enhancing political accountability. Thus, our work is related to at least three strands of literature: the growing set of studies that have analyzed public opinion towards globalization and its determinants; the research that has investigated the drivers of the voting behavior of elected officials on these matters in the U.S. Congress, and the more recent contributions 
that have studied the causal effect that media exposure has on political accountability.

The literature on public opinions has analyzed and emphasized the role that both economic and non-economic individual-level characteristics play in shaping preferences towards trade and migration. The main message that emerges from studies in this tradition is that economic drivers that work through the labor market and the welfare state do play an important role in informing opinions towards migration and (at least when it comes to the labor market channel) trade (see for instance Scheve and Slaughter 2001, Mayda and Rodrik 2005, Blonigen 2011, Facchini and Mayda 2008, Facchini and Mayda 2009 etc.). Non-economic drivers are also found to matter. This is true both in the case of opinions towards migration - where the role of cultural and national-identity issues and of racial and cultural prejudice has been emphasized (see Dustmann and Preston 2007 and Mayda 2006) - and towards trade (Mayda and Rodrik 2005), where patriotic and nationalistic feelings have been found to reduce support for opening up the economy to international competition. Importantly, while many studies have highlighted the role that the public's preferences play in a democratic society as a key driver of economic policy making (e.g. Rodrik 1995), very limited evidence is available on how this process actually takes place (for an exception, see Facchini and Mayda 2010).

The determinants of congressional action on trade and migration policy have been extensively analyzed. Several contributions have examined individual pieces of legislations (for trade, see for instance Baldwin 1985, Marks 1993 and Baldwin and Magee 2000; for migration, see Gonzalez and Kamdar 2000, Fetzer 2006). A few studies have instead taken a broader, longer term perspective. Hiscox (2002) has investigated the determinants of support for thirty major pieces of trade legislation introduced between 1824 and 1994 to compare the relative performance of the Heckscher-Ohlin and Ricardo-Viner models in explaining support for trade reforms. Conconi, Facchini, and Zanardi (2012) looked instead at the determinants of support for trade liberalization in the post-1970 era, considering fifteen major trade bills introduced in the period, and uncovering the important role played by election proximity in shaping protectionist behavior. Milner and Tingley (2011) and Facchini and Steinhardt (2011) focus instead on a large set of migration policy reforms, introduced after 1970, and investigate the role of both economic and non-economic determinants. In a recent paper, Conconi, Facchini, Steinhardt, and Zanardi (2012) consider congressional action on both trade and migration liberalization during the same period. Interestingly, they find that economic factors that work through the labor market play a similar role in both areas. Importantly, in these studies, the role of public opinion towards trade and migration is not explicitly considered as a driver of the voting behavior of individual representatives. The purpose of this paper is to fill this gap, by modeling the impact that the scrutiny of a representative's action by the media has in shaping her voting behavior. 
For this reason, this paper is also related to the growing literature in economics and political science that studies how the media shape public opinion and the electoral accountability of politicians. As argued by Ashworth (2012) in his recent review, the key challenge in this research area is to identify plausibly exogenous variation in the features that the theory identifies as important determinants of the responsiveness of politicians to their electorate. geography of congressional districts and the geography of media markets in the United States to trace the entire process through which an increase in information leads to greater or smaller responsiveness to election concerns. Interestingly, in their analysis of broad patterns in roll call votes, Snyder and Strömberg (2010) find that representatives of districts characterized by higher congruence tend to vote less often in line with their party orientation, and they also find that the extra news coverage induced by higher congruence makes representatives roll call votes less ideologically extreme. In our analysis of roll call votes on trade and migration we contribute to this literature by investigating whether the media's information transmission has a different impact depending on the saliency of the issue at stake, which as argued by Guisinger (2009) is likely to be comparatively high in the case of migration and low in the case of trade.

\section{Measuring media exposure}

Assessing the role of media exposure on a politician's responsiveness to his/her constituency preferences presents significant challenges. First and foremost, media coverage is typically endogenous vis a vis most of the outcome variables we might be interest in studying. For instance, consider the relationship between the role of the media and institutional quality. While several studies have found that countries where the media actively cover politics tend to be characterized by better governance structures, it is hard to conclude that media exposure causes an increase in accountability, as it is governments that are in the position to allow or not political coverage, and more corrupt governments have strong incentives to silence the press. Therefore, as it has been argued for instance by Besley and Prat (2006), active political coverage may simply reflect the fact that accountability and media coverage are jointly determined. Similarly, evidence suggesting that more political coverage results in better informed citizens can hardly be deemed causal, as both higher demand for news and better knowledge could be simply the result of the unobserved intrinsic preferences of the electorate for more information.

Several attempts have been made to address the potential endogeneity of media coverage with respect to political accountability. Particularly relevant for our analysis is the recent contribution by Snyder and Strömberg (2010), who introduce a measure of "congruence" between the electoral

district of a representative and the market for a local newspaper in the United States. To grasp 
the basic idea behind this research design, consider a metropolitan area including an inner city district and multiple suburban districts. In this example, it is likely that many of the suburban voters will obtain their local news from the paper based in the big city and sold all over the metropolitan area. If the newspaper dedicates more attention to the politician elected in the inner city district, then inner city voters will obtain more information on their representative than their suburban counterparts. If models of electoral accountability are correct, this will lead to greater responsiveness to the electorate for the inner city representative, closely scrutinized by the media, than for the representatives elected in the suburbs receiving only limited attention.

The basic assumption that must hold for this type of measure of political coverage to be exogenous is that the "economic geography" factors that shape media markets must be different from the "political geography" factors that determine congressional district boundaries. This is likely to be the case, as on the one hand congressional districts boundaries are drawn so that all districts in each state have the same population, representation is guaranteed to different racial groups, incumbents are protected etc. On the other hand, the boundaries of local newspaper markets are driven by other factors. in particular, they are typically based in urban areas, with strong demand for advertising and news about the city's public affairs. At the same time, their sales in the surrounding areas strongly depend on the distance between the suburb and the newspaper's headquarters and on the socio-economic characteristics of the area's residents. ${ }^{2}$ Formally, Snyder and Strömberg (2010) define their measure of congruence for district $d$ as follows:

$$
\text { Congruence }_{d}=\sum_{m} \text { MarketShare }_{m d} \text { ReaderShare } \text { Sd }_{\text {S }}
$$

where MarketShare $_{m d}$ indicates newspaper's $m$ share of total newspaper sales in district $d$, and Reader Share $_{m d}$ is the share of newspaper's $m$ readers that live in district $d$. This measure varies depending on both the number and size distribution of newspapers serving a given district, as well as on the importance that each district has for a newspaper's total sales. The measure ranges between zero and one, with the latter value representing a situation in which there is only one newspaper supplying a district and all the readers of that newspaper are concentrated in that district.

Using this measure, Snyder and Strömberg (2010) show that greater congruence implies that more information about the representative is available to a district's resident. In particular, their results suggest that "...congruence going from zero to one is associated with 170 more articles about the congressman appearing in an average paper selling in his or her district. It is associated with 100 more articles reaching an average household and around 30 more articles being read."

\footnotetext{
${ }^{2}$ For an excellent analysis of the working of the US newspaper market, see Fan (2013).
} 
Furthermore, they provide evidence that the average district resident takes advantage of this increased information flow and is better able to recognize her representative's name, ideological leanings etc.

For these reasons, Congruence appears to be a good proxy for the amount of information available to the constituency of a House Representative, and we will use it to study the role that media exposure might play in insuring that an elected politician's choices will reflect her constituency preferences on international economic policy.

\section{Data}

The construction of our dataset draws on a number of different sources. We collect information on legislative votes on trade and migration policy measures in the U.S. House of Representatives, which have been obtained from the Congressional Roll Call Voting Dataset of the Policy Agenda Project and the Library of Congress (THOMAS). Since these datasets provide only rough information about the content of the bills, we have supplemented them using additional sources, like the Congressional Quarterly publications and existing historical accounts like the ones by Gimpel and Edwards (1999) and Destler (2005) (see also Conconi et al. 2012 for more details).

As for legislation related to trade, we focus on all major trade bills ${ }^{3}$ introduced in the U.S. Congress between 1986 and 2004 (see Table 1). include in our analysis votes on the implementation of multilateral trade agreements (Tokyo and Uruguay Round rounds of the GATT) and preferential trade agreements (e.g. NAFTA) negotiated in this period, as well as the votes on the conferral and extension of fast track trade negotiating authority to the President, which, as it has been argued by the literature, makes it easier to negotiate trade agreements (see Conconi, Facchini, and Zanardi 2012). Most of the bills included in our analysis involve changes in trade policies with less developed countries. With respect to immigration, we restrict our analysis to bills with a potential impact on labor supply, i.e. that either regulate legal immigration or tackle illegal immigration. In particular, we exclude, for instance, bills that deal primarily with the provision of public goods to illegal migrants or the federal reimbursement of health and education costs to states.

We restrict our attention to final passage votes, which determine whether a bill clears the House or not. In particular, we do not consider votes on amendments. We follow this approach because voting on amendments is often strategic and therefore is less likely to distinctly reflect the interests of a legislator's constituency. Table 1 summarizes the votes on trade and immigration

\footnotetext{
${ }^{3}$ In particular we cover bills granting or extending fast track authority and ratifying bilateral or multilateral trade agreements.
} 
legislation that took place in the U.S. House of Representatives between 1986 and 2004, which constitute the basis of our empirical analysis. ${ }^{4}$

Next, we combine our data on trade and immigration bills with the corresponding records of individual voting behavior of House representatives. This information is provided by the VOTEVIEW project (http://voteview.ucsd.edu) of Poole and Rosenthal (1997). In addition, the VOTEVIEW database includes information on congressmen's name, party affiliation, state of residence, and congressional district, which enable us to link legislators to their constituencies. With respect to information on representatives' age and gender, we use data from three sources: up to 2000, we rely on ICPSR Study number 7803 and the data base built by Swift et al. (2000); from 2001 onwards, we rely on data provided by the Biographical Directory of the US Congress.

Finally, we match our data on individual voting records with information on the characteristics of electoral constituencies. For this purpose, we use data from the American National Election Studies (ANES), a biannual representative survey carried out in election years that contains detailed information on the place of residence of individual respondents, ${ }^{5}$ and the Congressional District Data Files of Adler (2003) and Lublin (1997), who have aggregated Census data at the congressional-district level, taking into account the decennial redistricting. We supplement them using information taken directly from the U.S. Census whenever needed.

Our dependent variables are the representative's votes on bills regulating trade (VoteTrade $d t$ ),

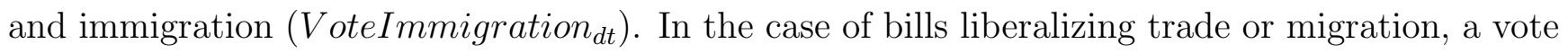
coded 1 indicates that the district's representative supports more open trade or immigration, and 0 otherwise. In the case of legislation restricting trade or immigration, a vote is coded 0 if the representative votes in favor of a restrictive policy and 1 otherwise. We have coded these variables so that a value of 1 indicates a vote supporting the liberalization of trade or immigration, or opposing their restriction. Conversely, a value of 0 indicates that the representative has voted in favor of restrictions (or against lifting restrictions) on trade or migration.

Our key explanatory variables are a measure of a district's preferences towards trade and migration and the indicator for congruence between media markets and congressional districts described in section 3. We assess individual opinions towards international economic policy using two questions that have been asked in several waves of the ANES. The question on trade reads as follows in 1986: "Some people have suggested placing new limits on imports in order to protect American jobs. Others say that such limits would raise consumer prices and hurt American

\footnotetext{
${ }^{4}$ Note that this is not an exhaustive list because of limits to the availability of our key explanatory variable. For details on the full sample of votes on migration and trade that took place in this period, see Conconi, Facchini, Steinhardt, and Zanardi (2012).

${ }^{5}$ This data has been used extensively in the literature. For recent analyses based on it, see for instance Snyder and Strömberg (2010) and Hanson, Scheve, and Slaughter (2007).
} 
exports. Do you favor placing new limits on imports, or not?" and the possible answers are "Favor new limits", "Oppose new limits" and "Don't know". Similar questions have been asked throughout the period. We have constructed a "pro-trade" dummy that takes a value of one if the respondent answered "Oppose new limits" and zero if the answer was "Favor new limits", while we have disregarded "Don’t know" replies. As for the question on migration, it reads as follows: "Do you think the number of immigrants from foreign countries who are permitted to come to the United States to live should be increased, stay as now, or decreased?". We have constructed a "pro-immigration" dummy that takes a value of one if the individual is in favor of increasing migration or leaving it as it is now, and zero otherwise. Also in this case we have disregarded "Don't know" and "Not available" replies. ${ }^{6}$

Two additional sets of drivers are used to explain voting behavior. The first focuses on districtlevel characteristics. As it has been argued in the literature (see for instance Conconi, Facchini, Steinhardt, and Zanardi 2012) a district's factor endowment might play an important role in shaping policy preferences, and we capture its role using the variable SkillRatio $_{d t}$, which measures the proportion of high-skilled individuals in the total population over 25 years of age at time $t$ in congressional district $d$. High-skilled individuals are defined as those having earned at least a bachelor's degree. To proxy for the sectoral structure of the local economy, we use instead the share of individuals in the labor force employed in each one digit sector. ${ }^{7}$ We also include in some of our robustness checks a measure of district-level unemployment, which is defined as the share of individuals in the total labor force not having a job, but have been looking for it in the past four weeks.

The literature on public opinions towards trade and migration has emphasized that the redistribution among different groups within society carried out by the welfare state is an important driver of preferences towards globalization (Hanson, Scheve, and Slaughter 2007, Rodrik 1998 and Mayda, O'Rourke, and Sinnott 2007). To capture the role of the welfare state in our analysis, we use two variables. First, we consider the mean family income within a district. Second, we include the ratio of average to median family income, which measures the extent of inequality within a district. including direct controls for the extent of state-level redistribution, measured by public spending on Welfare, Health and Hospitals, and Elementary and Secondary Education as a share of average personal income.

Our last set of district-level controls includes proxies for the degree of urbanization and ethnic composition. To this end we use Census data, and construct the variable Urban $d t$ that captures

\footnotetext{
${ }^{6}$ In our robustness checks we experiment with different definitions of both variables, obtaining broadly similar results.

${ }^{7}$ Details on the data construction are available from the National Historic Geographical Information System website, https://www.nhgis.org/ and Bureau of Labor Statistics website http://www.bls.gov/iag/home.htm.
} 
the share of the population living in urban areas, to account for potential differences in attitudes towards immigration and trade between rural and urban areas. Next, we define the variable Foreign - born $n_{d t}$, which measures the share of foreign-born in the district's population, and the variable Hispanic $d t$ to account for possible network effects influencing both support for trade and immigration liberalization. Finally, we explore the existence of possible coalitions among minorities in shaping migration policy by including African - Americandt, i.e. the share of blacks in the population.

The second set of drivers we include is given by standard individual-level controls for the representative's characteristics. We start with a measure of ideology, which is proxied by Democrat $t_{d t}$, a dummy variable taking a value of one if the representative is a member of the Democratic party. We have also used two alternative measures: the first dimension of the DW nominate score, and the ADA score, which have been normalized so that a higher score identifies a more liberal politician. 8 Age and gender have been shown to play a significant role in shaping individual attitudes towards trade and migration (see for instance Mayda and Rodrik 2005 and Facchini and Mayda 2009). For this reason, we also include these demographic characteristics of legislators in our analysis. The last individual-level controls we use are proxies for the influence of pressure groups on U.S. representatives. In particular, we employ data on labor and corporate Political Action Committees (PACs) contributions, which are provided by the Federal Election Commission (http://www.fec.gov/).

Opinions on trade and migration are not elicited in every bi-annual wave of the ANES. In particular, the former are available for the 1986 through 2000 and 2004 election cycles, and the latter for the 1992 through 2000 and 2004 election cycles. Thus, our sample covers those Congresses during which a bill on trade or migration came to the floor and information on public opinion on the two issues is available in the ANES. As a result, our analysis considers the 13 bills listed in Table 1. For an overview of the content of the various pieces of legislation we include in our analysis, see Conconi, Facchini, Steinhardt, and Zanardi (2012).

Table 2 provides summary statistics for the data used in our analysis, where we report separate figures for votes on trade and migration. The first stylized fact that emerges is the broad difference in support for trade and migration in the US House of Representatives: while in only $40 \%$ of our observations a vote in favor of freer immigration was recorded, the corresponding figure for trade was $63 \%$. Turning to our main explanatory variables, the value of congruence is remarkably similar in the two samples at just above 40 percent. As for the opinion variables, the mean value

\footnotetext{
${ }^{8}$ The DW-nominate measure is provided by the VOTEVIEW project (http://voteview.ucsd.edu), whereas the ADA score is constructed by the American for Democratic Action, a lobby group. The main difference between the former and the latter is that the ADA score uses only votes on a sub-sample of bills, whereas the DW nominate score employs every roll call votes in each congress, and is based on a more sophisticated estimation procedure.
} 
of the pro-trade dummy is $36 \%$ while the value of the pro-immigration dummy equals $45 \%$. Note, though, that given the difference in the phrasing of the two questions, the two measures are not directly comparable. ${ }^{9}$ As for the other regressors, they all appear not to differ significantly across samples.

Figures 1 and 2 highlight a clear pattern that emerges from the data. The first illustrates California's congressional districts 6 and 39 in 1998. Both districts are characterized by electorates that support more open immigration policies. In particular, over 53 percent of the population in district 6 and 69 percent of the population in district 39 have declared to be in favor of increasing migration or leaving it as it is now (panel (b)). At the same time, only district 6 exhibits a high level of congruence (57 percent), whereas district 39 is characterized by low levels of congruence (9 percent; see panel (c)). Interestingly, the representative from the "high congruence" district 6 voted in favor of freer migration, supporting H.R. 3736, whereas the representative of the "low congruence" district ended up opposing that bill (panel (d)).

Figure 2 focuses instead on Texas' districts 7 and 9 in 1998. Also in this case, public opinion in the two constituencies is similar: in both cases well over two thirds of the electorate is in favor of trade liberalization, but while in district 9 congruence is high at 63.2 percent, in the case of district 7 congruence is low, at approximately 14 percent. Importantly, in this case, there is no obvious relationship between the electorates' preferences and the voting behavior of House Representatives. Focusing on H.R. 2621, we see that Nick Lampson, elected in district 9 ended up voting against trade liberalization, even if the congruence between his district and the local newspaper market was very high, while William Archer Jr. ended up voting in favor of it even if congruence was low.

While this evidence suggests that congruence plays an important role in shaping the voting behavior of elected officials when it comes to migration, it also indicates that this is not true in the case of trade policy. In the remainder of the paper, we will systematically investigate the role that the media play in enhancing the accountability of elected officials on these two dimensions of international economic policy.

\section{Empirical Analysis}

In our empirical analysis we study to what extent the probability that a representative votes protrade or pro-migration depends on the preferences of its electorate and on the press coverage that

\footnotetext{
${ }^{9}$ Given that in our empirical analysis we will exploit the variation of opinions on each separate topic across districts, this is not a concern for the interpretation of our main results.
} 
the politician's behavior receives. Specifically, we estimate linear probability models of this form:

$$
\begin{aligned}
\text { Vote }_{d t} & =\left[\alpha^{1} \operatorname{MigOp}_{d t}+\beta^{1} \operatorname{Cong}_{d t}+\gamma^{1} \operatorname{MigOp}_{d t} \times \operatorname{Cong}_{d t}+\mathbf{X}_{d t} \delta+I_{s t}\right] \times \mathrm{M}_{d t}+ \\
& +\left[\alpha^{2} \operatorname{TradeOp}_{d t}+\beta^{2} \operatorname{Cong}_{d t}+\gamma^{2} \operatorname{TradeOp}_{d t} \times \operatorname{Cong}_{d t}+\mathbf{X}_{d t} \delta+I_{s t}\right] \times \mathrm{T}_{d t}+u_{d t}
\end{aligned}
$$

where Vote $_{d t}$ is a dummy variable which takes a value of one if the the representative of district $d$ has voted in favor of a bill liberalizing immigration or trade at time $t$. MigOpdt and TradeOp $p_{d t}$ are respectively the share of residents of district $d$ that are in favor of more open migration and trade policies in year $t$, and Cong $_{d t}$ is the measure of "congruence" between the electoral district and the market for local newspapers defined in section 3. These are our key variables of interest. The vector $\mathbf{X}_{d t}$ contains instead additional controls at the district and individual representative level. In particular, we account for district's economic characteristics - skill composition, unemployment rate, income level, sectoral composition of employment - and demographic features like the share of urban, foreign born and African-American in the population. As for the individual representative, we control for party affiliation, age and gender. In all our specifications we include also a set of indicator variables $I_{s t}$ to account for unobserved time- and state-specific effects, which can vary over time. To assess the differential effect of each of the explanatory variables in influencing the representative's voting behavior on trade and migration bills, we estimate a fully interacted model, with $M_{d t}$ and $T_{d t}$ denoting respectively votes on migration and trade. $u_{d t}$ is a mean zero idiosyncratic shock, which we assume to be uncorrelated with the explanatory variables. We account for the heteroscedasticity implied by the linear probability model using robust standard errors.

The key parameters of interest in our analysis are the coefficients $\gamma^{1}$ and $\gamma^{2}$. A positive sign indicates that an increase in congruence will make the elected official's behavior more in line with the prevailing opinion of her electorate. Conversely, a lack of significance would instead indicate the absence of any accountability-enhancing effect of press coverage.

Our main results are reported in Table 3. While we estimate the fully interacted model specified in equation 2, we have chosen to report each set of results in two separate columns, to simplify the comparison of the effects of the various drivers of votes on trade and migration bills. In column (1) we start with a parsimonious specification, that includes only our key explanatory variables and state-year interactions. The results show that the estimates of the coefficients of the interaction term between opinion and congruence is different between immigration and trade. In the former case it is positive and highly significant, whereas in the latter it is not different from zero. This suggests that - in the case of migration - higher congruence between the representatives' district and local newspapers' markets makes it more likely that the elected official will cast a ballot in 
accordance with the preferences of her constituency. This is not true for the case of trade.

When deciding how to vote, a representative is likely to have imperfect information on the exact distribution of opinions in the district. For this reason, she might base her choices on a broader set of socio-economic and demographic characteristics that would allow her to better infer the preferences of her electorate. In column (2) we start by controlling also for the skill composition, unemployment rate and mean family income of the district. In column (3) we additionally account for the sectoral composition of employment by including the share of employees in each one digit sector, whereas in column (4) we include also a set of district level demographic controls, i.e. the share of the urban population, the share of foreign born and the share of African Americans. Last, in column (5) we add also a set of representative's characteristics including her party affiliation, age and gender. In particular, introducing all these additional controls does not alter the sign, significance and magnitude of our key coefficient of interest. Moreover, focusing on the result reported in column (5), several interesting patterns emerge. First, our findings suggest that a higher average skill level is associated to a more open stance towards migration, while this effect is not significant for trade. At the same time, an increase in unemployment negatively affects the politician's support for trade liberalization, whereas it has no effect for migration. As for family income, it does not play a role on either dimension of international economic policy. Turning to sectoral cleavages, we find that the share of workers employed in agriculture positively affects support for trade liberalization, and this result could be driven by the comparative advantage enjoyed by the United States in agricultural products. We also detect a positive impact of employment in the wholesale and retail trade and transportation sector on support for migration liberalization, and this finding could be driven by the fact that these service sectors tend to employ large numbers of immigrants.

Finally, we find that districts characterized by a higher share of foreign born tend to be more in favor of both migration and trade liberalization. This result is likely to be driven by the role that ethnic channels play in channeling support for migration, as well as by the role that ethnic networks play in international trade. During the first half of our sample in particular, growing regional integration with Mexico and other Latin American countries was at the forefront of the political debate and several latino pressure groups were actively engaged in the promotion of these preferential trading arrangements (see Baldwin and Magee 2000, Lindsay 2002).

All other controls do not play a role. Finally, among the representatives' characteristics, we find that only affiliation with the democratic party has an effect, negatively influencing support for trade liberalization, whereas it has a positive impact on migration, even if the latter is not statistically significant. These results are broadly consistent with previous findings in the literature (see for instance Conconi, Facchini, Steinhardt, and Zanardi (2012), Baldwin and Magee (2000) 
etc.). ${ }^{10}$

To quantify the impact of public opinion on the representative's voting behavior on migration and trade, we focus on our benchmark specification in column (5), and in Figure 3 we illustrate how the marginal effect of public opinion on the representative's voting behavior changes with congruence. Panel (a) focuses on migration, whereas panel (b) illustrates the effect for trade. As we can see, the marginal impact of a district's average opinion on support for migration is not statistically significant for low levels of congruence. For values of congruence above 0.43 the effect becomes instead positive and significant at the five percent level. As a result, in a district characterized by slightly above average congruence - like Florida's 4th in 1996 - a ten percentage points increase $^{11}$ in the share of the population which favors pro-migration policies would lead to a 2.9 percentage points ${ }^{12}$ increase in the probability of the representative casting a pro-migration vote. At the same time, for a congressional district with a congruence score of 0.70 (at the 90th percentile of the congruence distribution) like Pennsylvania's 5th congressional district in 1998, the same increase in the share of pro-migrant's population would lead to a 7.7 percentage points (over $15 \%$ of a standard deviation) increase in the probability of a pro-migration vote. On the other hand, as it is apparent from panel (b) of the figure, even for very high levels of congruence, public opinion does not significantly affect a representative's voting behavior on trade policy.

\section{Additional results}

In this section, we assess the robustness of our empirical findings by implementing a number of additional specifications. We start by introducing a series of new economic and non economic controls at the district level, we turn then to consider different measures of the representative's characteristics and finally experiment with an alternative econometric methodology.

In Table 4 we start by reporting in column (1), for comparison purposes, the results of our benchmark specification, i.e. column (5) of Table 3. In column (2) we replace our measure of a district's individual preferences on trade and migration based on the average value of our promigration and pro-trade dummies with measures based on their median values. The basic pattern uncovered in Table (3) continues to hold. Higher congruence between the representative's district and local newspaper market increases the likelihood that an elected official will vote according to her constituency's preferences on migration, but not on trade. The other results remain broadly unaffected. In column (3) instead of using the mean or the median of our pro-migration dummy,

\footnotetext{
${ }^{10}$ Note that - differently from previous studies in the literature - in all our specifications we are already capturing the pro-migration stance of the democratic electorate by including average opinions in the district.

${ }^{11}$ Corresponding to approximately half a standard deviation.

${ }^{12}$ Corresponding to about $6 \%$ of a standard deviation.
} 
we take full advantage of the three possible answers for the migration question listed in the ANES survey - "increased", "same as now" and "decreased" - and code them as 2, 1 and 0 respectively. We then use the mean of this variable in our regression, and obtain results which are similar to those in the benchmark. ${ }^{13}$ In column (4) and (5) we further explore the role that welfare state considerations might play in shaping a representative's voting behavior on international economic policy. In column (4) we control for median rather than mean family income in the district, whereas in column (5) we include also a measure of the extent of inequality within the district. Neither of these controls appear to play an important role, but more importantly, they do not affect our main results. ${ }^{14}$

In Table (5) we start once again by reporting in column (1) the results from our benchmark specification. In column (2) we additionally control for a representative's education, using information taken from the Congressional Directories and digitized in ICPSR study 3371. Interestingly, we find that representatives who attended an Ivy League school are more likely to support both immigration and trade liberalization than members of the House who either did not go to college or attended another type of higher education institution, even if only the latter effect is strongly statistically significant. In columns (3) and (4) we experiment with alternative measures of the ideological orientation of the representative and replace democratic party affiliation with the normalized DW nominate score (column 3) and ADA score (column 4). More liberal leaning representatives are more likely to vote against trade liberalization and in favor of migration liberalization. Importantly, using these alternative proxies for ideological leaning does not affect our main result.

So far, our analysis has focused on the role played by the opinions of the districts' average or median voter. In column 5 of Table 5 , we include information on organized groups, which have received great attention both in the trade literature ${ }^{15}$ and in the literature on migration. ${ }^{16}$ Our measure of the intensity of the lobbying activity is given by Political Action Committee Contributions (PACs), which can be easily traced to the elected officials receiving them. In particular, we focus on the role played by contributions offered by corporations (PacCorporate) and by unions (PacLabor). As PACs measure lobbying effort on a variety of different issues, we have considered a politician to have been "influenced" if the corporate (labor) contributions he/she has received are at or above the eightieth percentile of all corporate (labor) contributions in that

\footnotetext{
${ }^{13}$ Note that the answer to the trade question only takes two values, and as a result we cannot carry out a similar robustness check.

${ }^{14}$ Note that any heterogeneity in the size of welfare provisions at the state level are already accounted for with the inclusion of a full set of state-year interactions.

${ }^{15}$ See for instance the theoretical analysis by Grossman and Helpman (1994) and the empirical implementations by Goldberg and Maggi (1999) and Gawande and Bandyopadhyay (2000).

${ }^{16}$ See Facchini and Willmann (2005), Hanson and Spilimbergo (2001) and Facchini, Mayda, and Mishra (2011).
} 
year. $^{17}$

In line with the existing literature, we find that lobbying activities do affect the voting behavior of elected representatives on trade policy. In particular, larger contributions by labor organizations tend to result in a more protectionist bias by the politician, whereas larger contributions by business related lobbies have the opposite effect. This result confirms earlier findings by Baldwin and Magee (2000). At the same time, corporate and labor PAC contributions do not appear to affect the voting behavior of elected officials on immigration policy. This is in line with the findings of Facchini, Mayda, and Mishra (2011), who show that PAC contributions are not a significant driver of immigration policy, whereas the opposite is true for lobbying expenditure directly related to migration policy. ${ }^{18}$

Our last set of robustness checks concerns the econometric methodology we have followed. All of our specifications have been run using linear probability models. We have employed this approach because the linear probability model is consistent under weak assumptions, it works well with fixed effects, and its coefficient estimates - especially in the presence of interaction terms are simple to interpret. In Table A1 in the Appendix we reproduce our main results from Table 3 using instead a probit specification and reporting the corresponding coefficient values. As it can be immediately seen, the broad patterns we have identified in Table 3 continue to hold.

\section{Conclusions}

In this paper we have carried out what is - to the best of our knowledge - the first empirical analysis of the effect of public opinion on trade and migration on individual representatives' voting behavior. Focusing on the role of local newspapers, we have shown that large information flows make elected congressmen more accountable to their constituency on a politically salient issue like international migration, whereas we do not find a systematic effect when it turns to international trade. Thus our paper suggests that - at least when it comes to international economic policy making - the interplay of saliency and information is key to understand the policy maker's behavior.

We can think of at least two directions along which our analysis could be extended. First, the empirical measure we have used for the information conveyed to the electorate is based on the congruence between the market for local newspapers and electoral districts. In recent years,

\footnotetext{
${ }^{17}$ We have experimented with different thresholds, and the qualitative results are unaffected.

${ }^{18}$ Facchini, Mayda, and Mishra (2011) use a dataset that allows to identify the purpose of the lobbying activity in the United States, showing that pressure groups at the sectoral level have a statistically significant and important effect on the allocation of work and related visas. Unfortunately, this data cannot be used in our analysis of congressmen's voting behavior, since it does not contain information on the identity of politicians contacted by lobbies.
} 
the printed press has seen its readership decline and at the same time new media have started to play an increasingly important role. In particular, in the recent US presidential campaign social media and blogs have been the focus of much attention ${ }^{19}$, and it would be interesting to construct indicators that would allow us to measure the individual's exposure to these additional sources and assess their effect on electoral discipline.

Second, our analysis has pointed out the role that the salience of the issue plays in making the elected official accountable to her electorate. It would be interesting to investigate whether the pattern we have identified for migration and trade policy holds also in other areas, like like gun control or environmental issues. While these are interesting questions, they are left for further research.

\section{References}

Adler, E. S. (2003). Congressional District File, 93d-104th Congress. University of Colorado at Boulder.

Arkolakis, C., A. Costinot, and A. R. Clare (2012). New trade models, same old gains? American Economic Review, 94-130.

Ashworth, S. (2012). Electoral accountability: Recent theoretical and empirical work. Annual Review of Political Sceice 15, 183-201.

Baldwin, R. (1985). The Political Economy of US import policy. Cambridge, MA: MIT Press.

Baldwin, R. E. and C. S. Magee (2000). Is trade policy for sale? Congressional voting on recent trade bills. Public Choice 105(1/2), 79-101.

Besley, T. and A. Prat (2006). Handcuffs for the grabbing hand? Media capture and government accountability. American Economic Review 96(3), 720-736.

Blonigen, B. A. (2011). Revisiting the evidence on trade policy preferences. Journal of International Economics 85, 129-135.

Conconi, P., G. Facchini, M. F. Steinhardt, and M. Zanardi (2012). The political economy of trade and migration: Evidence from the U.S. congress. Dp 9270, CEPR.

Conconi, P., G. Facchini, and M. Zanardi (2012). Fast track authority and international trade negotiations. American Economic Journal: Economic Policy 4, 146-189.

\footnotetext{
${ }^{19}$ See for instance the recent article by David Rehr "Social media's impact on the presidential election" available at http://www.huffingtonpost.com/david-k-rehr/social-medias-impact-on-t_b_2504414.html.
} 
Destler, I. M. (2005). American Trade Politics. Washington, DC: Institute for International Economics.

di Giovanni, J., A. Levchenko, and F. Ortega (2012). A global view of cross-border migration. Dp 1218, CREAM.

Dustmann, C. and I. Preston (2007). Racial and economic factors in attitudes to immigration. The B.E. Journal of Economic Analysis 8 Policy 7, Article 62.

Facchini, G. and A. M. Mayda (2008). From individual attitudes towards migrants to migration policy outcomes: Theory and evidence. Economic Policy. forthcoming.

Facchini, G. and A. M. Mayda (2009). Individual attitudes towards immigrants: Welfare-state determinants across countries. Review of Economics and Statistics 91, 295-314.

Facchini, G. and A. M. Mayda (2010). What drives immigration policy? Evidence based on a survey of government's officials. In G. S. Epstein and I. N. Gang (Eds.), Migration and Culture, pp. 605-648. Bingley, United Kingdom: Emerald.

Facchini, G., A. M. Mayda, and P. Mishra (2011). Do interest group affect U.S. immigration policy? Journal of International Economics 85, 114-128.

Facchini, G. and M. F. Steinhardt (2011). What drives U.S. immigration policy? Evidence from congressional roll call votes. Journal of Public Economics 95, 734-743.

Facchini, G. and G. Willmann (2005). The political economy of international factor mobility. Journal of International Economics 67, 201-219.

Fan, Y. (2013). Ownership consolidation and product characteristics: A study of the US daily newspaper market. American Economic Review 103, 1598-1628.

Feenstra, R. C. (1995). Estimating the effects of trade policy. In G. M. Grossman and K. Rogoff (Eds.), Handbook of International Economics, Volume 3, pp. 1553-1595. Amsterdam and New York: North Holland.

Fetzer, J. S. (2006). Why did house members vote for H.R.4437? International Migration Review 40, 698-706.

Gawande, K. and U. Bandyopadhyay (2000). Is protection for sale? Evidence on the GrossmanHelpman theory of endogenous protection. Review of Economics and Statistics 82, 139-152.

Gimpel, J. G. and J. R. Edwards (1999). The congressional politics of immigration reform. Boston: Allyn and Bacon.

Goldberg, P. K. and G. Maggi (1999). Protection for sale: An empirical investigation. American Economic Review 89, 1135-55. 
Gonzalez, J. G. and N. Kamdar (2000). Do not give me your tired, your poor! Determinants of legislator voting on immigration issues. Eastern Economic Journal 26, 127-143.

Grossman, G. M. and E. Helpman (1994). Protection for sale. American Economic Review 84, 833-850.

Guisinger, A. (2009). Determining trade policies: Do voters hold politicians accountable? International Organization 63, 533-557.

Hamilton, R. and J. Whalley (1984). Efficiency and distributional implications of global restrictions on labour mobility: Calculations and policy implications. Journal of Development Economics 14, 61-75.

Hanson, G. H., K. F. Scheve, and M. J. Slaughter (2007). Public finance and individual preferences over globalization strategies. Economics \& Politics 19, 1-33.

Hanson, G. H. and A. Spilimbergo (2001). Political economy, sectoral shocks, and border enforcement. Canadian Journal of Economics 34, 612-638.

Hiscox, M. J. (2002). Commerce, coalitions and factor mobility: Evidence from congressional votes on trade legislation. American Political Science Review 96, 1-16.

Lindsay, J. M. (2002). Getting Uncle Sam's ear: Will ethnic lobbies cramp America's foreign policy style. mimeo, Brookings Institution.

Lublin, D. (1997). Congressional District Demographic and Political Data. American University.

Marks, S. V. (1993). Economic interests and voting on the omnibus trade bill of 1987. Public Choice 75, 21-42.

Mayda, A. M. (2006). Who is against immigration? A cross-country investigation of individual attitudes toward immigrants. Review of Economics and Statistics 88, 510-530.

Mayda, A. M., K. O’Rourke, and R. Sinnott (2007). Risk, government and globalization: International survey evidence. mimeo, Georgetown University.

Mayda, A. M. and D. Rodrik (2005). Why are some people (and countries) more protectionist than others? European Economic Review 49, 1393-1430.

Milner, H. V. and D. Tingley (2011). The economic and political influences on different dimensions of United States immigration policy. mimeo, Princeton University.

Poole, K. T. and H. Rosenthal (1997). A political-economic history of roll call voting. New York: Oxford University Press. 
Rodrik, D. (1995). Political Economy of trade policy. In G. M. Grossman and K. Rogoff (Eds.), Handbook of International Economics, Volume 3, pp. 1457-1494. Amsterdam and New York: North Holland.

Rodrik, D. (1998). Why do more open economies have bigger governments? Journal of Political Economy 106, 997-1032.

Scheve, K. F. and M. J. Slaughter (2001). Labor market competition and individual preferences over immigration policy. Review of Economics and Statistics 83, 133-145.

Snyder, J. M. and D. Strömberg (2010). Press coverage and political accountability. Journal of Political Economy 118, 355-408.

Swift, E., R. Brookshire, D. Canon, E. Fink, J. Hibbing, B. Humes, M. Malbin, and K. Martis (2000). Database of Congressional Historical Statistics. Interuniversity Consortium for Political and Social Research. 


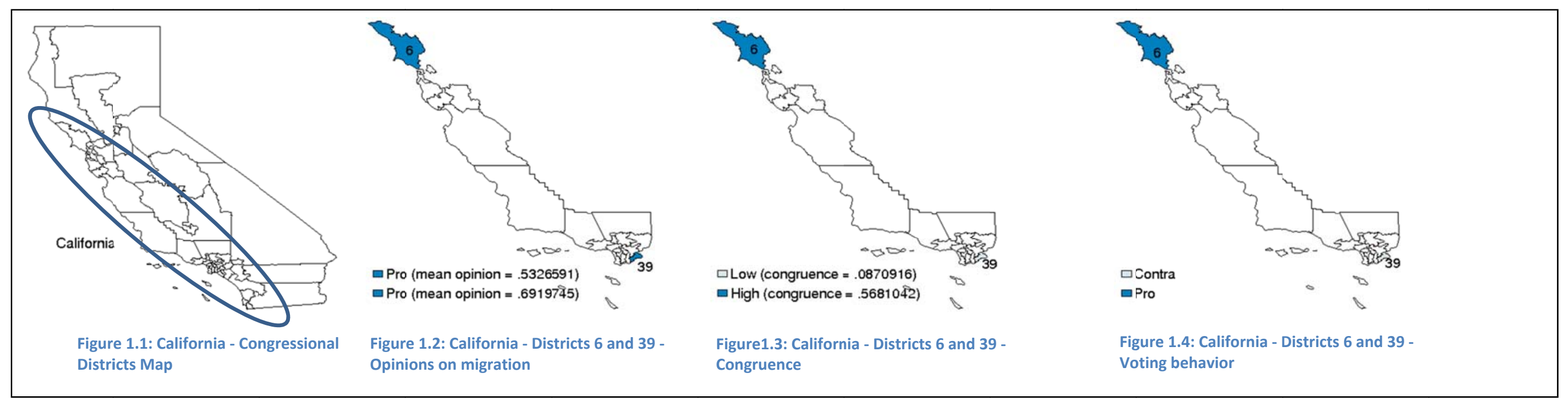

Figure 1: Individual opinions on migration, congruence and voting behavior on HR 3736 (1998)

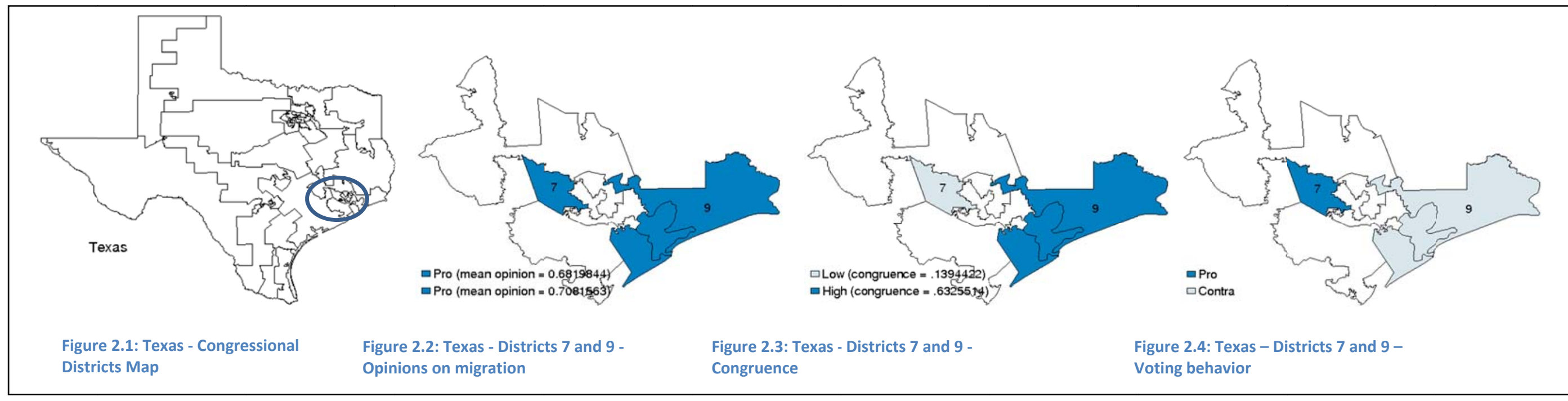

Figure 2: Individual opinions on trade, congruence and voting behavior on HR 2621 (1998) 
Figure 3a: Marginal effect of district's migration opinion on Representative's voting behavior

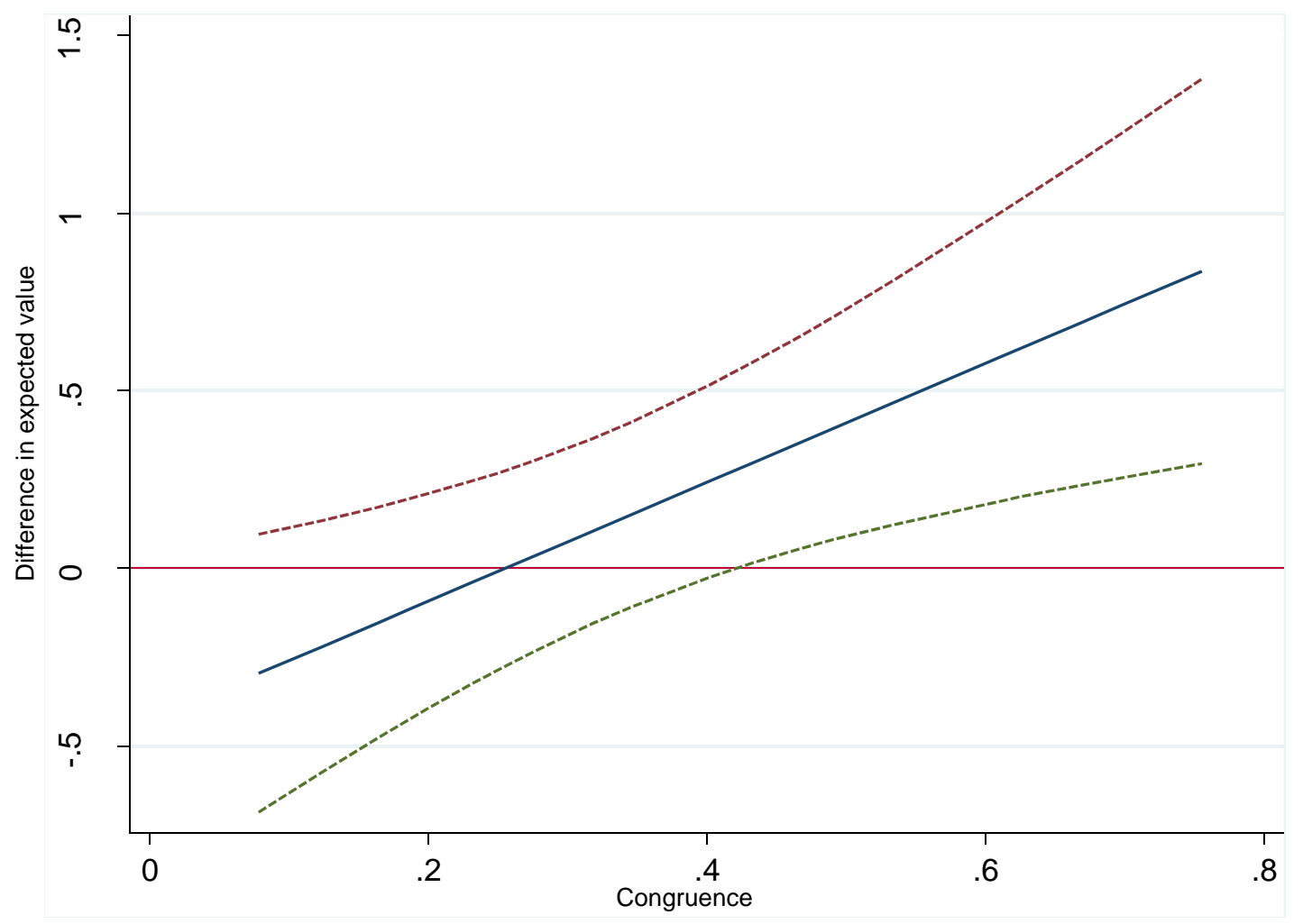

Figure 3b: Marginal effect of district's trade opinion on Representative's voting behavior

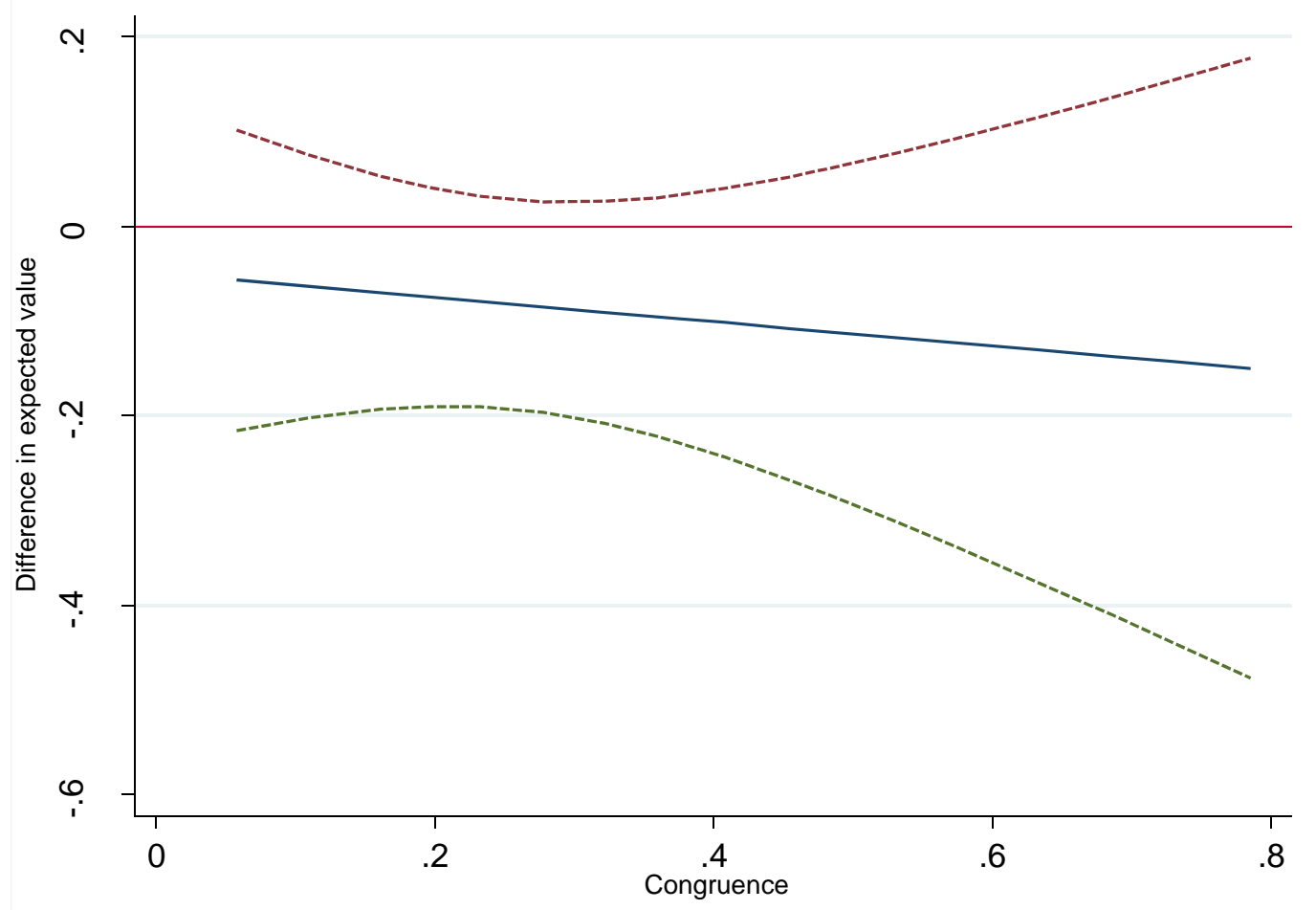


Table 1: Final passage votes on trade and migration reforms in the House of Representatives 1970-2006

\begin{tabular}{|c|c|c|c|c|c|c|c|c|c|c|c|}
\hline \multirow[b]{2}{*}{ Cong. } & \multirow[b]{2}{*}{ Date } & \multirow[b]{2}{*}{ Bill } & \multirow[b]{2}{*}{ Description } & \multirow[b]{2}{*}{ Issue } & \multirow[b]{2}{*}{ Dir } & \multicolumn{3}{|c|}{ Votes } & \multicolumn{3}{|c|}{ Districts covered in ANES } \\
\hline & & & & & & Yes & No & Sum & Yes & No & Sum \\
\hline 99 & 22.05.1986 & H.R.4800 & $\begin{array}{c}\text { Omnibus Trade Bill, incl. } \\
\text { fast track authority } \\
\text { Omnibus Trade and }\end{array}$ & Trade & Contra & 295 & 115 & 410 & 70 & 36 & 106 \\
\hline 100 & 13.07.1988 & H.R.4848 & $\begin{array}{l}\text { Competitiveness Act, } \\
\text { incl. fast track authority }\end{array}$ & Trade & Pro & 376 & 45 & 421 & 73 & 14 & 87 \\
\hline 100 & 09.08.1988 & H.R.5090 & Approval of CUSFTA & Trade & Pro & 366 & 40 & 406 & 75 & 10 & 85 \\
\hline 103 & 22.06.1993 & H.R.1876 & $\begin{array}{c}\text { Extension of fast track } \\
\text { authority }\end{array}$ & Trade & Pro & 295 & 126 & 421 & 92 & 42 & 134 \\
\hline 103 & 17.11.1993 & H.R.3450 & Approval of NAFTA & Trade & Pro & 234 & 200 & 434 & 64 & 73 & 137 \\
\hline 103 & 29.11.1994 & H.R.5110 & $\begin{array}{l}\text { Approval of Uruguay } \\
\text { Round Agreements }\end{array}$ & Trade & Pro & 288 & 146 & 434 & 77 & 33 & 110 \\
\hline 105 & 25.09.1998 & H.R.2621 & $\begin{array}{c}\text { Approval of fast track } \\
\text { authority }\end{array}$ & Trade & Pro & 180 & 243 & 423 & 42 & 52 & 94 \\
\hline 108 & 24.07.2003 & H.R.2738 & $\begin{array}{c}\text { Approval of US-Chile } \\
\text { FTA }\end{array}$ & Trade & Pro & 270 & 156 & 426 & 59 & 42 & 101 \\
\hline 108 & 24.07.2003 & H.R.2739 & $\begin{array}{l}\text { Approval of US- } \\
\text { Singapore FTA }\end{array}$ & Trade & Pro & 272 & 155 & 427 & 61 & 42 & 103 \\
\hline 108 & 14.07.2004 & H.R.4759 & $\begin{array}{l}\text { Approval of US- } \\
\text { Australia FTA }\end{array}$ & Trade & Pro & 314 & 109 & 423 & 66 & 28 & 94 \\
\hline 108 & 22.07.2004 & H.R.4842 & $\begin{array}{c}\text { Approval of US-Morocco } \\
\text { FTA }\end{array}$ & Trade & Pro & 323 & 99 & 422 & 65 & 23 & 88 \\
\hline 104 & 21.03.1996 & H.R.2202 & $\begin{array}{l}\text { Illegal Immigration } \\
\text { Reform and Immigrant } \\
\text { Responsibility Act }\end{array}$ & Migration & Contra & 333 & 87 & 420 & 127 & 46 & 173 \\
\hline 105 & 25.09.1998 & H.R.3736 & $\begin{array}{c}\text { Skilled Workers and H- } \\
\text { 1B }\end{array}$ & Migration & Pro & 288 & 133 & 421 & 61 & 31 & 92 \\
\hline
\end{tabular}

Cong. and Date describe the congress/date in which/when the vote took place. Bill shows the name under which the bill is originating in the House of Representatives (“H.R.”). Description provides some basic information about the content of the legislation. Dir. shows whether the bill is pro or contra liberalizing trade. In "Votes": Yes/No show the overall number of Yes/No Votes, Sum shows the overall number of votes. In "Districts covered in Anes" we only focus on those distrcicts for which we have observations on opinion in the American National Election Survey dataset. All figures are calculated on the basis of individual voting records. FTA stands for free trade area. 
Table 2: Summary statistics

\begin{tabular}{|c|c|c|c|c|c|c|}
\hline Variable & & Obs & Mean & Std. Dev. & Min & Max \\
\hline \multirow[t]{2}{*}{ Vote $_{d t}$} & Migration & 265 & 0.402 & 0.491 & 0 & 1 \\
\hline & Trade & 1139 & 0.627 & 0.484 & 0 & 1 \\
\hline \multirow[t]{2}{*}{ Mean Opinion $_{d t}$} & Migration & 265 & 0.445 & 0.211 & 0 & 1 \\
\hline & Trade & 1139 & 0.363 & 0.246 & 0 & 1 \\
\hline \multirow[t]{2}{*}{ Congruence $_{d t}$} & Migration & 265 & 0.401 & 0.214 & 0.038 & 0.821 \\
\hline & Trade & 1139 & 0.430 & 0.226 & 0.035 & 0.893 \\
\hline \multirow[t]{2}{*}{ SkillRatio $_{d t}$} & Migration & 265 & 0.200 & 0.093 & 0.053 & 0.514 \\
\hline & Trade & 1139 & 0.194 & 0.087 & 0.041 & 0.569 \\
\hline \multirow{2}{*}{ Unemployment $_{d t}$} & Migration & 265 & 0.062 & 0.028 & 0.018 & 0.204 \\
\hline & Trade & 1139 & 0.064 & 0.026 & 0.018 & 0.219 \\
\hline \multirow[t]{2}{*}{ Log mean family income $d t$} & Migration & 265 & 3.733 & 0.289 & 3.124 & 4.681 \\
\hline & Trade & 1139 & 3.698 & 0.455 & 2.400 & 4.954 \\
\hline \multirow{2}{*}{ Farmer $_{d t}$} & Migration & 265 & 0.022 & 0.021 & 0.002 & 0.209 \\
\hline & Trade & 1139 & 0.022 & 0.023 & 0.000 & 0.209 \\
\hline \multirow[t]{2}{*}{ Construction $_{d t}$} & Migration & 265 & 0.058 & 0.015 & 0.023 & 0.130 \\
\hline & Trade & 1139 & 0.059 & 0.017 & 0.010 & 0.130 \\
\hline \multirow[t]{2}{*}{ Manufacturing $_{d t}$} & Migration & 265 & 0.159 & 0.059 & 0.047 & 0.313 \\
\hline & Trade & 1139 & 0.174 & 0.068 & 0.038 & 0.347 \\
\hline \multirow[t]{2}{*}{ Wholesale, Retail and Transportation $_{d t}$} & Migration & 265 & 0.238 & 0.022 & 0.171 & 0.314 \\
\hline & Trade & 1139 & 0.225 & 0.028 & 0.130 & 0.304 \\
\hline \multirow[t]{2}{*}{ Finance $_{d t}$} & Migration & 265 & 0.064 & 0.023 & 0.022 & 0.159 \\
\hline & Trade & 1139 & 0.061 & 0.022 & 0.022 & 0.171 \\
\hline \multirow[t]{2}{*}{ Professionals $_{d t}$} & Migration & 265 & 0.066 & 0.023 & 0.030 & 0.164 \\
\hline & Trade & 1139 & 0.066 & 0.030 & 0.024 & 0.197 \\
\hline \multirow[t]{2}{*}{ Education and Health ${ }_{d t}$} & Migration & 265 & 0.174 & 0.031 & 0.078 & 0.262 \\
\hline & Trade & 1139 & 0.180 & 0.035 & 0.092 & 0.310 \\
\hline \multirow{2}{*}{ Entertainment Services $_{d t}$} & Migration & 265 & 0.014 & 0.009 & 0.006 & 0.095 \\
\hline & Trade & 1139 & 0.040 & 0.032 & 0.006 & 0.183 \\
\hline \multirow[t]{2}{*}{ Public Administration $_{d t}$} & Migration & 265 & 0.050 & 0.026 & 0.016 & 0.192 \\
\hline & Trade & 1139 & 0.048 & 0.024 & 0.016 & 0.243 \\
\hline \multirow[t]{2}{*}{ Urban $_{d t}$} & Migration & 265 & 0.667 & 0.290 & 0.034 & 1 \\
\hline & Trade & 1139 & 0.695 & 0.271 & 0.001 & 1 \\
\hline \multirow[t]{2}{*}{ Foreign - born ${ }_{d t}$} & Migration & 265 & 0.078 & 0.085 & 0.004 & 0.585 \\
\hline & Trade & 1139 & 0.076 & 0.086 & 0.004 & 0.585 \\
\hline \multirow[t]{2}{*}{ African - American $_{d t}$} & Migration & 265 & 0.139 & 0.187 & 0.001 & 0.739 \\
\hline & Trade & 1139 & 0.131 & 0.173 & 0.001 & 0.921 \\
\hline \multirow[t]{2}{*}{ Age representative $_{d t}$} & Migration & 265 & 51.208 & 9.238 & 29 & 86 \\
\hline & Trade & 1139 & 50.882 & 9.861 & 28 & 85 \\
\hline \multirow[t]{2}{*}{ Gender representative $_{d t}$} & Migration & 265 & 0.086 & 0.281 & 0 & 1 \\
\hline & Trade & 1139 & 0.076 & 0.266 & 0 & 1 \\
\hline \multirow[t]{2}{*}{ Democrat $_{d t}$} & Migration & 265 & 0.479 & 0.501 & 0 & 1 \\
\hline & Trade & 1139 & 0.508 & 0.500 & 0 & 1 \\
\hline
\end{tabular}

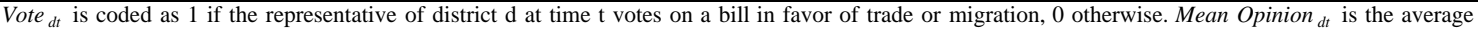
opinion of district $\mathrm{d}$ at time $\mathrm{t}$ and ranges between 0 and 1 (the closer to 1 the more in favor of trade liberalization or pro-immigration). Congruence measures the match between newspaper markets and U.S. congressional districts. SkillRatio $d t$ measures the percentage of the population over 25 with at least a bachelor degree. Unemployment ${ }_{d t}$ is the share of unemployed individuals in the total labor force. Log mean family income $d t$ measures the logarithm of mean family income within a district in dollars. Farmer ${ }_{d t}$ measures the share of farm workers in the total labor force. Construction ${ }_{d t}$ measures the share of people employed in construction in the total labor force. Manufacturing $d t$ is the share of people employed in the manufacturing industry in the total laborforce. Wholesale, Retail and Transportation ${ }_{d t}$ is the share of people employed in the wholesale, retail trade and transportation sectors in the total labor force. Finance $_{d t}$ measures the share of people employed in the financial, insurance and real estate industry in the total labor force. Professionals ${ }_{d t}$ measures the share of people employed in professional, scientific, management, administrative, and waste management services in the total labor force. Education and Health $_{d t}$ is the share of people employed in the educational sector and in the health and social services sector in the total labor force. Entertainment Services $_{d t}$ measures the share of people employed in the entertainment, recreation, accommodation and food services industries in the total labor force. Public Administration ${ }_{d t}$ measures the share of individuals employed in public administration in the total labor force. Urban $d t$ is a measure of the share of population living in urban areas. Foreign - born ${ }_{d t}$ is the share of foreign-born individuals in the total population. African - American $d t$ is the share of African-American individuals in the total population. Age - representative ${ }_{d t}$ is the age of congressperson of district $\mathrm{i}$ at the beginning of current congress. Gender - representative ${ }_{d t}$ is coded as 1 for female congresspersons, 0 otherwise. Democrat ${ }_{d t}$ is coded as 1 if the representative of the district belongs to the Democratic Party. 


\begin{tabular}{|c|c|c|c|c|c|c|c|c|c|c|}
\hline & \multicolumn{2}{|c|}{ (1) } & \multicolumn{2}{|c|}{ (2) } & \multicolumn{2}{|c|}{ (3) } & \multicolumn{2}{|c|}{ (4) } & \multicolumn{2}{|c|}{$\begin{array}{l}\text { (5) } \\
\end{array}$} \\
\hline & Migration & Trade & Migration & Trade & Migration & Trade & Migration & Trade & Migration & Trade \\
\hline Opinion $_{d t}$ & $\begin{array}{l}-0.236 \\
(0.234)\end{array}$ & $\begin{array}{c}-0.0777 \\
(0.0962)\end{array}$ & $\begin{array}{l}-0.288 \\
(0.238)\end{array}$ & $\begin{array}{c}-0.136 \\
(0.0941)\end{array}$ & $\begin{array}{l}-0.316 \\
(0.221)\end{array}$ & $\begin{array}{c}-0.142 \\
(0.0914)\end{array}$ & $\begin{array}{c}-0.446^{* *} \\
(0.225)\end{array}$ & $\begin{array}{c}-0.156^{*} \\
(0.093)\end{array}$ & $\begin{array}{l}-0.428 * \\
(0.227)\end{array}$ & $\begin{array}{c}-0.0495 \\
(0.0949)\end{array}$ \\
\hline Cogruence $_{d t}$ & $\begin{array}{c}-0.775^{* *} \\
(0.311)\end{array}$ & $\begin{array}{c}-0.0374 \\
(0.146)\end{array}$ & $\begin{array}{l}-0.627^{*} \\
(0.363)\end{array}$ & $\begin{array}{l}0.0836 \\
(0.149)\end{array}$ & $\begin{array}{c}-0.654 * \\
(0.375)\end{array}$ & $\begin{array}{c}-0.345^{* *} \\
(0.173)\end{array}$ & $\begin{array}{l}-0.441 \\
(0.381)\end{array}$ & $\begin{array}{c}-0.278 \\
(0.188)\end{array}$ & $\begin{array}{l}-0.315 \\
(0.385)\end{array}$ & $\begin{array}{l}-0.225 \\
(0.18)\end{array}$ \\
\hline Interaction $_{d t}$ & $\begin{array}{c}1.694 * * * \\
(0.603)\end{array}$ & $\begin{array}{c}0.474 \\
(0.303)\end{array}$ & $\begin{array}{c}1.685^{* * *} \\
(0.58)\end{array}$ & $\begin{array}{c}0.256 \\
(0.305)\end{array}$ & $\begin{array}{c}1.663^{* * *} \\
(0.549)\end{array}$ & $\begin{array}{c}0.217 \\
(0.293)\end{array}$ & $\begin{array}{c}1.783^{* * * *} \\
(0.544)\end{array}$ & $\begin{array}{c}0.235 \\
(0.295)\end{array}$ & $\begin{array}{c}1.674 * * * \\
(0.557)\end{array}$ & $\begin{array}{l}-0.128 \\
(0.298)\end{array}$ \\
\hline SkillRatio $_{d t}$ & & & $\begin{array}{l}1.584^{*} \\
(0.881)\end{array}$ & $\begin{array}{c}0.126 \\
(0.439)\end{array}$ & $\begin{array}{l}3.435^{*} \\
(1.776)\end{array}$ & $\begin{array}{c}2.220 * * * \\
(0.732)\end{array}$ & $\begin{array}{c}3.978^{* *} \\
(1.751)\end{array}$ & $\begin{array}{c}2.233^{* * *} \\
(0.728)\end{array}$ & $\begin{array}{c}3.782 * * \\
(1.824)\end{array}$ & $\begin{array}{c}1.058 \\
(0.731)\end{array}$ \\
\hline Unemployment $_{d t}$ & & & $\begin{array}{c}3.608 \\
(2.723)\end{array}$ & $\begin{array}{c}-3.452^{* * *} \\
(1.268)\end{array}$ & $\begin{array}{l}6.597 * \\
(3.817)\end{array}$ & $\begin{array}{c}-3.929 * * * \\
(1.425)\end{array}$ & $\begin{array}{c}5.396 \\
(3.554)\end{array}$ & $\begin{array}{c}-3.614^{* *} \\
(1.532)\end{array}$ & $\begin{array}{l}5.513^{*} \\
(3.348)\end{array}$ & $\begin{array}{l}-2.543^{*} \\
(1.538)\end{array}$ \\
\hline Log mean family income $d t$ & & & $\begin{array}{l}-0.287 \\
(0.402)\end{array}$ & $\begin{array}{c}0.207 \\
(0.197)\end{array}$ & $\begin{array}{l}-0.762 \\
(0.512)\end{array}$ & $\begin{array}{l}-0.261 \\
(0.221)\end{array}$ & $\begin{array}{c}-0.74 \\
(0.507)\end{array}$ & $\begin{array}{l}-0.212 \\
(0.23)\end{array}$ & $\begin{array}{l}-0.558 \\
(0.523)\end{array}$ & $\begin{array}{l}-0.196 \\
(0.217)\end{array}$ \\
\hline Farmer $_{d t}$ & & & & & $\begin{array}{c}2.687 \\
(3.211)\end{array}$ & $\begin{array}{c}6.078^{* * *} \\
(1.588)\end{array}$ & $\begin{array}{c}3.644 \\
(3.259)\end{array}$ & $\begin{array}{c}5.752^{* * *} \\
(1.675)\end{array}$ & $\begin{array}{c}4.218 \\
(3.197)\end{array}$ & $\begin{array}{c}3.795^{* *} \\
(1.709)\end{array}$ \\
\hline Construction $_{d t}$ & & & & & $\begin{array}{c}3.884 \\
(4.483)\end{array}$ & $\begin{array}{c}4.896 * * * \\
(1.889)\end{array}$ & $\begin{array}{c}6.188 \\
(4.315)\end{array}$ & $\begin{array}{c}5.343^{* * *} \\
(1.976)\end{array}$ & $\begin{array}{c}6.476 \\
(4.515)\end{array}$ & $\begin{array}{l}1.784 \\
(2.07)\end{array}$ \\
\hline Manufacturing $_{d t}$ & & & & & $\begin{array}{c}1.944 \\
(2.633)\end{array}$ & $\begin{array}{l}0.743 \\
(1.09)\end{array}$ & $\begin{array}{c}2.494 \\
(2.445)\end{array}$ & $\begin{array}{c}0.875 \\
(1.091)\end{array}$ & $\begin{array}{c}2.681 \\
(2.408)\end{array}$ & $\begin{array}{l}0.139 \\
(1.12)\end{array}$ \\
\hline Wholesale, Retail and Transportation $_{d t}$ & & & & & $\begin{array}{c}3.908 \\
(3.156)\end{array}$ & $\begin{array}{l}-0.367 \\
(1.468)\end{array}$ & $\begin{array}{c}4.866 \\
(3.097)\end{array}$ & $\begin{array}{l}-0.407 \\
(1.488)\end{array}$ & $\begin{array}{l}6.118 * * \\
(3.052)\end{array}$ & $\begin{array}{l}-1.701 \\
(1.485)\end{array}$ \\
\hline Finance $_{d t}$ & & & & & $\begin{array}{c}2.341 \\
(3.909)\end{array}$ & $\begin{array}{c}2.44 \\
(1.735)\end{array}$ & $\begin{array}{c}1.779 \\
(3.766)\end{array}$ & $\begin{array}{c}2.523 \\
(1.712)\end{array}$ & $\begin{array}{c}2.084 \\
(3.662)\end{array}$ & $\begin{array}{c}0.895 \\
(1.706)\end{array}$ \\
\hline Professionals $_{d t}$ & & & & & $\begin{array}{c}0.634 \\
(4.909)\end{array}$ & $\begin{array}{l}-3.547^{*} \\
(2.143)\end{array}$ & $\begin{array}{l}-1.398 \\
(4.946)\end{array}$ & $\begin{array}{c}-4.115^{* *} \\
(2.047)\end{array}$ & $\begin{array}{l}-1.179 \\
(4.781)\end{array}$ & $\begin{array}{l}-3.337 \\
(2.126)\end{array}$ \\
\hline Education and Health $_{d t}$ & & & & & $\begin{array}{l}0.0718 \\
(2.666)\end{array}$ & $\begin{array}{c}-0.0813 \\
(1.269)\end{array}$ & $\begin{array}{c}0.186 \\
(2.422)\end{array}$ & $\begin{array}{c}0.361 \\
(1.317)\end{array}$ & $\begin{array}{c}0.286 \\
(2.298)\end{array}$ & $\begin{array}{c}0.127 \\
(1.355)\end{array}$ \\
\hline Entertainment Services $_{d t}$ & & & & & $\begin{array}{c}2.769 \\
(4.878)\end{array}$ & $\begin{array}{l}1.192 \\
(1.91)\end{array}$ & $\begin{array}{c}3.634 \\
(4.528)\end{array}$ & $\begin{array}{c}1.197 \\
(1.902)\end{array}$ & $\begin{array}{c}3.62 \\
(4.472)\end{array}$ & $\begin{array}{c}0.758 \\
(1.848)\end{array}$ \\
\hline Public Administration $_{d t}$ & & & & & $\begin{array}{c}0.00956 \\
(2.841)\end{array}$ & $\begin{array}{c}1.925 \\
(1.371)\end{array}$ & $\begin{array}{c}0.53 \\
(2.712)\end{array}$ & $\begin{array}{l}2.419^{*} \\
(1.364)\end{array}$ & $\begin{array}{c}0.809 \\
(2.767)\end{array}$ & $\begin{array}{c}1.956 \\
(1.433)\end{array}$ \\
\hline Urban $_{d t}$ & & & & & & & $\begin{array}{l}0.0648 \\
(0.217)\end{array}$ & $\begin{array}{c}0.00946 \\
(0.165)\end{array}$ & $\begin{array}{l}-0.0237 \\
(0.218)\end{array}$ & $\begin{array}{c}0.215 \\
(0.164)\end{array}$ \\
\hline Foreign - born ${ }_{d t}$ & & & & & & & $\begin{array}{c}1.311^{* *} \\
(0.55)\end{array}$ & $\begin{array}{c}0.47 \\
(0.292)\end{array}$ & $\begin{array}{c}1.166^{* *} \\
(0.54)\end{array}$ & $\begin{array}{l}0.626^{* *} \\
(0.284)\end{array}$ \\
\hline African - American $_{d t}$ & & & & & & & $\begin{array}{c}0.471 \\
(0.407)\end{array}$ & $\begin{array}{c}-0.0685 \\
(0.187)\end{array}$ & $\begin{array}{c}0.548 \\
(0.403)\end{array}$ & $\begin{array}{c}-0.24 \\
(0.184)\end{array}$ \\
\hline Age - representative $_{d t}$ & & & & & & & & & $\begin{array}{c}0.00482 \\
(0.00369)\end{array}$ & $\begin{array}{c}0.00003 \\
(0.00176)\end{array}$ \\
\hline Gender - representative $_{d t}$ & & & & & & & & & $\begin{array}{l}0.0796 \\
(0.114)\end{array}$ & $\begin{array}{c}-0.0188 \\
(0.0666)\end{array}$ \\
\hline Democrat $_{d t}$ & & & & & & & & & $\begin{array}{c}0.106 \\
(0.0871)\end{array}$ & $\begin{array}{c}-0.334 * * * \\
(0.0481)\end{array}$ \\
\hline
\end{tabular}

\begin{tabular}{lcccc}
\hline State*year fixed effect & YES & YES & YES & YES \\
\hline Observations & 1404 & 1404 & 1404 & 1404 \\
R-squared & 0.294 & 0.344 & 0.381 & 1404 \\
\hline \hline
\end{tabular}

The dependent variable is the dummy Vote $e_{d t}$ which is coded as 1 if the representative of district $\mathrm{d}$ at time $\mathrm{t}$ votes on a bill in favor of trade or migration, 0 otherwise. Mean Opinion $_{d t}$ is the average opinion of district $\mathrm{d}$ at time $\mathrm{t}$ and ranges between 0 and 1 (the closer to 1 the more in favor of trade liberalization or pro-immigration). Congruence $_{d t}$ measures the match between newspaper markets and U.S. congressional districts. Interaction ${ }_{d t}$ measures the interaction between Mean Opinion ${ }_{d t}$ and Congruence $_{d t}$. SkillRatio $_{d t}$ measures the percentage of the population over 25 with at least a bachelor degree. Unemployment $d t$ is the share of unemployed individuals in the total labor force. Log mean family income ${ }_{d t}$ measures the logarithm of mean family income within a district. Farmer - share $e_{d t}$ measures the share of farm workers in the total labor force. Construction ${ }_{d t}$ measures the share of people employed in construction in the total labor force. Manufacturing $d t$ is the share of people employed in the manufacturing industry in the total laborforce. Wholesale, Retail and Transportation ${ }_{d t}$ is the share of people employed in the wholesale, retail trade and transportation sectors in the total labor force. Financed $t_{t}$ measures the share of people employed in the financial, insurance and real estate industry in the total labor force. Professionals $d t$ measures the share of people employed in professional, scientific, management, administrative, and waste management services in the total labor force. Education and Health ${ }_{d t}$ is the share of people employed in the educational sector and in the health and social services sector in the total labor force. Entertainment Services ${ }_{d t}$ measures the share of people employed in the entertainment, recreation, accommodation and food services industries in the total labor force. Public Administration $d t$ measures the share of individuals employed in public administration in the total labor force. Urban ${ }_{d t}$ is a measure of the share of population living in urban areas. Foreign - born ${ }_{d t}$ is the share of foreign-born individuals in the total population. African - American $d t$ is the share of AfricanAmerican individuals in the total population. Age - representative $d t$ is the age of congressperson of district i at the beginning of current congress. Gender representative $_{d t}$ is coded as 1 for female congress persons, 0 otherwise. Democrat ${ }_{d t}$ is coded as 1 if the representative of the district belongs to the Democratic Party. 


\begin{tabular}{|c|c|c|c|c|c|c|c|c|c|c|}
\hline & \multicolumn{2}{|c|}{ (1) } & \multicolumn{2}{|c|}{$\begin{array}{l}\text { (2) } \\
\end{array}$} & \multicolumn{2}{|c|}{ (3) } & \multicolumn{2}{|c|}{ (4) } & \multicolumn{2}{|c|}{ (5) } \\
\hline & Migration & Trade & Migration & Trade & Migration & Trade & Migration & Trade & Migration & Trade \\
\hline Mean opinion $_{d t}$ & $\begin{array}{l}-0.428^{*} \\
(0.227)\end{array}$ & $\begin{array}{c}-0.0495 \\
(0.095)\end{array}$ & & & & $\begin{array}{c}-0.0495 \\
(0.095)\end{array}$ & $\begin{array}{c}-0.395 * \\
(0.225)\end{array}$ & $\begin{array}{c}-0.0515 \\
(0.095)\end{array}$ & $\begin{array}{l}-0.398 * \\
(0.224)\end{array}$ & $\begin{array}{l}-0.0523 \\
(0.095)\end{array}$ \\
\hline Median opinion $_{d t}$ & & & $\begin{array}{l}-0.263^{*} \\
(0.139)\end{array}$ & $\begin{array}{c}-0.0113 \\
(0.068)\end{array}$ & & & & & & \\
\hline Mean opinion rescaled $d t$ & & & & & $\begin{array}{c}-0.331^{* *} \\
(0.159)\end{array}$ & & & & & \\
\hline Congruence $_{d t}$ & $\begin{array}{l}-0.315 \\
(0.385)\end{array}$ & $\begin{array}{c}-0.225 \\
(0.180)\end{array}$ & $\begin{array}{c}0.158 \\
(0.341)\end{array}$ & $\begin{array}{c}-0.272 * \\
(0.157)\end{array}$ & $\begin{array}{l}-0.247 \\
(0.388)\end{array}$ & $\begin{array}{l}-0.225 \\
(0.180)\end{array}$ & $\begin{array}{l}-0.327 \\
(0.387)\end{array}$ & $\begin{array}{l}-0.228 \\
(0.179)\end{array}$ & $\begin{array}{l}-0.328 \\
(0.388)\end{array}$ & $\begin{array}{c}-0.23 \\
(0.180)\end{array}$ \\
\hline Interaction (mean opinion) $_{d t}$ & $\begin{array}{c}1.674 * * * \\
(0.557)\end{array}$ & $\begin{array}{c}-0.128 \\
(0.298)\end{array}$ & & & & $\begin{array}{l}-0.128 \\
(0.298)\end{array}$ & $\begin{array}{c}1.622^{* * *} \\
(0.553)\end{array}$ & $\begin{array}{l}-0.127 \\
(0.298)\end{array}$ & $\begin{array}{c}1.626^{* * *} \\
(0.552)\end{array}$ & $\begin{array}{l}-0.126 \\
(0.298)\end{array}$ \\
\hline Interaction (median opinion) $_{d t}$ & & & $\begin{array}{l}0.658 * \\
(0.349)\end{array}$ & $\begin{array}{c}-0.0329 \\
(0.183)\end{array}$ & & & & & & \\
\hline Interaction opinion rescaled $_{d t}$ & & & & & $\begin{array}{c}1.264^{* * *} \\
(0.452)\end{array}$ & & & & & \\
\hline SkillRatio $_{d t}$ & $\begin{array}{l}3.782 * * \\
(1.824)\end{array}$ & $\begin{array}{c}1.058 \\
(0.731)\end{array}$ & $\begin{array}{l}3.736^{* *} \\
(1.849)\end{array}$ & $\begin{array}{c}1.086 \\
(0.735)\end{array}$ & $\begin{array}{l}3.385^{*} \\
(1.798)\end{array}$ & $\begin{array}{c}1.058 \\
(0.731)\end{array}$ & $\begin{array}{l}3.734^{* *} \\
(1.710)\end{array}$ & $\begin{array}{c}1.052 \\
(0.700)\end{array}$ & $\begin{array}{l}3.811^{* *} \\
(1.831)\end{array}$ & $\begin{array}{c}1.053 \\
(0.734)\end{array}$ \\
\hline Unemployment $_{d t}$ & $\begin{array}{l}5.513^{*} \\
(3.348)\end{array}$ & $\begin{array}{l}-2.543^{*} \\
(1.538)\end{array}$ & $\begin{array}{l}6.681 * \\
(3.462)\end{array}$ & $\begin{array}{l}-2.513 \\
(1.547)\end{array}$ & $\begin{array}{c}5.223 \\
(3.430)\end{array}$ & $\begin{array}{c}-2.543 * \\
(1.538)\end{array}$ & $\begin{array}{c}4.487 \\
(3.509)\end{array}$ & $\begin{array}{c}-2.82 \\
(1.724)\end{array}$ & $\begin{array}{c}4.53 \\
(3.549)\end{array}$ & $\begin{array}{l}-2.888 \\
(1.827)\end{array}$ \\
\hline Log mean family income $d t$ & $\begin{array}{l}-0.558 \\
(0.523)\end{array}$ & $\begin{array}{l}-0.196 \\
(0.217)\end{array}$ & $\begin{array}{l}-0.503 \\
(0.524)\end{array}$ & $\begin{array}{c}-0.202 \\
(0.219)\end{array}$ & $\begin{array}{l}-0.509 \\
(0.524)\end{array}$ & $\begin{array}{l}-0.196 \\
(0.217)\end{array}$ & & & $\begin{array}{l}-0.622 \\
(0.538)\end{array}$ & $\begin{array}{c}-0.223 \\
(0.231)\end{array}$ \\
\hline Log median family income $d t$ & & & & & & & $\begin{array}{l}-0.597 \\
(0.484)\end{array}$ & $\begin{array}{l}-0.218 \\
(0.229)\end{array}$ & & \\
\hline Inequality $_{d t}$ & & & & & & & & & $\begin{array}{c}0.407 \\
(0.588)\end{array}$ & $\begin{array}{c}0.194 \\
(0.337)\end{array}$ \\
\hline Farmer $_{d t}$ & $\begin{array}{c}4.218 \\
(3.197)\end{array}$ & $\begin{array}{c}3.795^{* *} \\
(1.709)\end{array}$ & $\begin{array}{c}4.54 \\
(3.222)\end{array}$ & $\begin{array}{c}3.828 * * \\
(1.692)\end{array}$ & $\begin{array}{c}3.998 \\
(3.139)\end{array}$ & $\begin{array}{c}3.795^{* *} \\
(1.709)\end{array}$ & $\begin{array}{c}3.669 \\
(2.931)\end{array}$ & $\begin{array}{c}3.640^{* *} \\
(1.713)\end{array}$ & $\begin{array}{c}3.756 \\
(3.159)\end{array}$ & $\begin{array}{c}3.629 * * \\
(1.707)\end{array}$ \\
\hline Wholesale, Retail and Transportation $_{d t}$ & $\begin{array}{l}6.118^{* *} \\
(3.052)\end{array}$ & $\begin{array}{l}-1.701 \\
(1.485)\end{array}$ & $\begin{array}{l}7.344^{* *} \\
(3.036)\end{array}$ & $\begin{array}{l}-1.589 \\
(1.481)\end{array}$ & $\begin{array}{l}5.877 * \\
(3.036)\end{array}$ & $\begin{array}{l}-1.701 \\
(1.485)\end{array}$ & $\begin{array}{l}6.118^{* *} \\
(3.005)\end{array}$ & $\begin{array}{c}-1.6 \\
(1.476)\end{array}$ & $\begin{array}{l}6.070 * * \\
(3.007)\end{array}$ & $\begin{array}{l}-1.583 \\
(1.490)\end{array}$ \\
\hline Urban $_{d t}$ & $\begin{array}{l}-0.0237 \\
(0.218)\end{array}$ & $\begin{array}{l}0.215 \\
(0.164)\end{array}$ & $\begin{array}{l}(0.078) \\
(0.223)\end{array}$ & $\begin{array}{l}0.210 \\
(0.163)\end{array}$ & $\begin{array}{l}(0.009) \\
(0.217)\end{array}$ & $\begin{array}{l}0.215 \\
(0.164)\end{array}$ & $\begin{array}{c}(0.009) \\
-0.217\end{array}$ & $\begin{array}{l}0.220 \\
(0.166)\end{array}$ & $\begin{array}{l}(0.006) \\
(0.219)\end{array}$ & $\begin{array}{l}0.221 \\
(0.166)\end{array}$ \\
\hline Foreign - born $d t$ & $\begin{array}{l}1.166^{* *} \\
(0.540)\end{array}$ & $\begin{array}{c}0.626^{* *} \\
(0.284)\end{array}$ & $\begin{array}{l}1.285^{* *} \\
(0.551)\end{array}$ & $\begin{array}{c}0.619 * * \\
(0.283)\end{array}$ & $\begin{array}{l}1.147 * * \\
(0.537)\end{array}$ & $\begin{array}{c}0.626^{* *} \\
(0.284)\end{array}$ & $\begin{array}{l}1.089 * * \\
(0.551)\end{array}$ & $\begin{array}{c}0.594^{* *} \\
(0.285)\end{array}$ & $\begin{array}{l}1.096^{* *} \\
(0.556)\end{array}$ & $\begin{array}{c}0.592 * * \\
(0.283)\end{array}$ \\
\hline African - American $_{d t}$ & $\begin{array}{c}0.548 \\
(0.403)\end{array}$ & $\begin{array}{c}-0.24 \\
(0.184)\end{array}$ & $\begin{array}{c}0.546 \\
(0.400)\end{array}$ & $\begin{array}{c}-0.224 \\
(0.183)\end{array}$ & $\begin{array}{c}0.567 \\
(0.403)\end{array}$ & $\begin{array}{c}-0.24 \\
(0.184)\end{array}$ & $\begin{array}{c}0.543 \\
(0.400)\end{array}$ & $\begin{array}{c}-0.241 \\
(0.183)\end{array}$ & $\begin{array}{c}0.543 \\
(0.400)\end{array}$ & $\begin{array}{l}-0.239 \\
(0.185)\end{array}$ \\
\hline Age - representative $_{d t}$ & $\begin{array}{c}0.00482 \\
(0.004)\end{array}$ & $\begin{array}{c}0.00003 \\
(0.002)\end{array}$ & $\begin{array}{l}0.0049 \\
(0.004)\end{array}$ & $\begin{array}{c}-0.00005 \\
(0.002)\end{array}$ & $\begin{array}{c}0.00454 \\
(0.004)\end{array}$ & $\begin{array}{c}0.00003 \\
(0.002)\end{array}$ & $\begin{array}{c}0.00459 \\
(0.004)\end{array}$ & $\begin{array}{c}-0.00004 \\
(0.002)\end{array}$ & $\begin{array}{l}0.0046 \\
(0.004)\end{array}$ & $\begin{array}{c}-0.00004 \\
(0.002)\end{array}$ \\
\hline Gender - representative $_{d t}$ & $\begin{array}{l}0.0796 \\
(0.114)\end{array}$ & $\begin{array}{c}-0.0188 \\
(0.067)\end{array}$ & $\begin{array}{l}0.0801 \\
(0.111)\end{array}$ & $\begin{array}{c}-0.0172 \\
(0.066)\end{array}$ & $\begin{array}{l}0.0756 \\
(0.113)\end{array}$ & $\begin{array}{c}-0.0188 \\
(0.067)\end{array}$ & $\begin{array}{l}0.0654 \\
(0.116)\end{array}$ & $\begin{array}{l}-0.023 \\
(0.066)\end{array}$ & $\begin{array}{l}0.0662 \\
(0.116)\end{array}$ & $\begin{array}{l}-0.0235 \\
(0.067)\end{array}$ \\
\hline Democrat $_{d t}$ & $\begin{array}{c}0.106 \\
(0.087)\end{array}$ & $\begin{array}{c}-0.334^{* * *} \\
(0.048)\end{array}$ & $\begin{array}{c}0.109 \\
(0.091)\end{array}$ & $\begin{array}{c}-0.334^{* * *} \\
(0.048)\end{array}$ & $\begin{array}{c}0.106 \\
(0.088)\end{array}$ & $\begin{array}{c}-0.334^{* * *} \\
(0.048)\end{array}$ & $\begin{array}{l}0.0994 \\
(0.088)\end{array}$ & $\begin{array}{c}-0.334^{* * *} \\
(0.048)\end{array}$ & $\begin{array}{l}0.0989 \\
(0.089)\end{array}$ & $\begin{array}{c}-0.334^{* * *} \\
(0.048)\end{array}$ \\
\hline State*year fixed effect & & & & & $\mathrm{YH}$ & & & & & \\
\hline Other sectors & & & & & $\mathrm{YH}$ & & Y & & & \\
\hline Observations & & & & & 14 & & 14 & & & \\
\hline R-squared & & & & & 0.4 & & & & & \\
\hline
\end{tabular}

The dependent variable is the dummy Vote ${ }_{d t}$ which is coded as 1 if the representative of district $\mathrm{d}$ at time t votes on a bill in favor of trade or migration, 0 otherwise.

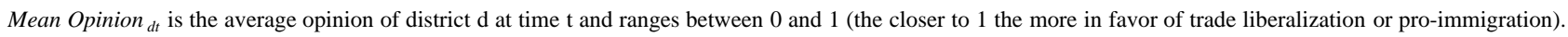

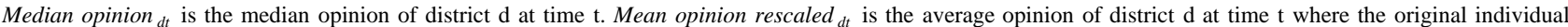
opinion variable is a categorical variable taking values 2, 1 and 0 (the closer to 2 the more in favor of immigration). Congruence $d t$ measures the match between newspaper markets and U.S. congressional districts. Interaction ${ }_{d t}$ measures the interaction between Mean Opinion ${ }_{d t}$ and Congruence ${ }_{d t}$. SkillRatio ${ }_{d t}$ measures the percentage of the population over 25 with at least a bachelor degree. Unemployment ${ }_{d t}$ is the share of unemployed individuals in the total labor force. Log mean family income $_{d t}$ measures the logarithm of mean family income within a district. Log median family income $d t$ measures the logarithm of median family income within a district. Inequality $_{d t}$ is the ratio of average to median family income within a district. Farmer ${ }_{d t}$ measures the share of farm workers in the total labor force. Wholesale, Retail and Transportation ${ }_{d t}$ is the share of people employed in the wholesale, retail trade and transportation sectors in the total labor force. Urban ${ }_{d t}$ is a measure of the share of population living in urban areas. Foreign - born ${ }_{d t}$ is the share of foreign-born individuals in the total population. African - American ${ }_{d t}$ is the share of African-American individuals in the total population. Age - representative $d t$ is the age of congressperson of district $\mathrm{i}$ at the beginning of current congress. Gender - representative $e_{d t}$ is coded as 1 for female congresspersons, 0 otherwise. Democrat ${ }_{d t}$ is coded as 1 if the representative of the district belongs to the Democratic Party. 


\begin{tabular}{|c|c|c|c|c|c|c|c|c|c|c|}
\hline & \multicolumn{2}{|c|}{ (1) } & \multicolumn{2}{|c|}{ (2) } & \multicolumn{2}{|c|}{ (3) } & \multicolumn{2}{|c|}{ (4) } & \multicolumn{2}{|c|}{ (5) } \\
\hline & Migration & Trade & Migration & Trade & Migration & Trade & Migration & Trade & Migration & Trade \\
\hline Opinion $_{d t}$ & $\begin{array}{l}-0.428 * \\
(0.227)\end{array}$ & $\begin{array}{c}-0.0495 \\
(0.095)\end{array}$ & $\begin{array}{l}-0.418^{*} \\
(0.226)\end{array}$ & $\begin{array}{c}-0.0454 \\
(0.095)\end{array}$ & $\begin{array}{l}-0.394^{*} \\
(0.226)\end{array}$ & $\begin{array}{c}-0.0749 \\
(0.095)\end{array}$ & $\begin{array}{l}-0.362 \\
(0.239)\end{array}$ & $\begin{array}{c}-0.0526 \\
(0.093)\end{array}$ & $\begin{array}{l}-0.365 \\
(0.232)\end{array}$ & $\begin{array}{c}0.00187 \\
(0.093)\end{array}$ \\
\hline Congruence $_{d t}$ & $\begin{array}{l}-0.315 \\
(0.385)\end{array}$ & $\begin{array}{l}-0.225 \\
(0.180)\end{array}$ & $\begin{array}{l}-0.319 \\
(0.387)\end{array}$ & $\begin{array}{l}-0.283 \\
(0.180)\end{array}$ & $\begin{array}{l}-0.226 \\
(0.387)\end{array}$ & $\begin{array}{c}-0.322 * \\
(0.185)\end{array}$ & $\begin{array}{l}-0.222 \\
(0.396)\end{array}$ & $\begin{array}{c}-0.374 * * \\
(0.183)\end{array}$ & $\begin{array}{l}-0.173 \\
(0.411)\end{array}$ & $\begin{array}{l}-0.279 \\
(0.172)\end{array}$ \\
\hline Interaction $_{d t}$ & $\begin{array}{c}1.674^{* * *} \\
(0.557)\end{array}$ & $\begin{array}{l}-0.128 \\
(0.298)\end{array}$ & $\begin{array}{c}1.642 * * * \\
(0.551)\end{array}$ & $\begin{array}{l}-0.214 \\
(0.297)\end{array}$ & $\begin{array}{c}1.592^{* * *} \\
(0.551)\end{array}$ & $\begin{array}{c}0.00702 \\
(0.293)\end{array}$ & $\begin{array}{c}1.536 * * * \\
(0.572)\end{array}$ & $\begin{array}{l}-0.057 \\
(0.293)\end{array}$ & $\begin{array}{l}1.413^{* *} \\
(0.579)\end{array}$ & $\begin{array}{c}-0.2 \\
(0.292)\end{array}$ \\
\hline SkillRatio $_{d t}$ & $\begin{array}{l}3.782 * * \\
(1.824)\end{array}$ & $\begin{array}{c}1.058 \\
(0.731)\end{array}$ & $\begin{array}{l}3.926^{* *} \\
(1.842)\end{array}$ & $\begin{array}{c}0.983 \\
(0.715)\end{array}$ & $\begin{array}{l}3.992 * * \\
(1.830)\end{array}$ & $\begin{array}{c}1.176 \\
(0.739)\end{array}$ & $\begin{array}{l}3.599 * \\
(1.954)\end{array}$ & $\begin{array}{c}1.394 * \\
(0.721)\end{array}$ & $\begin{array}{c}4.009^{* *} \\
(1.801)\end{array}$ & $\begin{array}{c}1.013 \\
(0.706)\end{array}$ \\
\hline Unemployment $_{d t}$ & $\begin{array}{l}5.513 * \\
\text { (3.348) }\end{array}$ & $\begin{array}{l}-2.543^{*} \\
(1.538)\end{array}$ & $\begin{array}{l}5.587^{*} \\
(3.368)\end{array}$ & $\begin{array}{l}-2.703^{*} \\
(1.540)\end{array}$ & $\begin{array}{c}5.478 \\
(3.344)\end{array}$ & $\begin{array}{c}-3.637^{* *} \\
(1.533)\end{array}$ & $\begin{array}{c}3.556 \\
(3.166)\end{array}$ & $\begin{array}{c}-3.830^{* *} \\
(1.542)\end{array}$ & $\begin{array}{c}4.273 \\
(3.337)\end{array}$ & $\begin{array}{l}-2.920^{*} \\
(1.531)\end{array}$ \\
\hline Log mean family income $d t$ & $\begin{array}{l}-0.558 \\
(0.523)\end{array}$ & $\begin{array}{l}-0.196 \\
(0.217)\end{array}$ & $\begin{array}{l}-0.583 \\
(0.526)\end{array}$ & $\begin{array}{l}-0.177 \\
(0.214)\end{array}$ & $\begin{array}{l}-0.543 \\
(0.519)\end{array}$ & $\begin{array}{l}-0.219 \\
(0.222)\end{array}$ & $\begin{array}{l}-0.562 \\
(0.530)\end{array}$ & $\begin{array}{c}-0.249 \\
(0.214)\end{array}$ & $\begin{array}{l}-0.603 \\
(0.531)\end{array}$ & $\begin{array}{l}-0.202 \\
(0.202)\end{array}$ \\
\hline Farmer $_{d t}$ & $\begin{array}{c}4.218 \\
(3.197)\end{array}$ & $\begin{array}{l}3.795^{* *} \\
(1.709)\end{array}$ & $\begin{array}{c}4.063 \\
(3.199)\end{array}$ & $\begin{array}{l}3.449 * * \\
(1.693)\end{array}$ & $\begin{array}{c}4.178 \\
(3.145)\end{array}$ & $\begin{array}{c}4.880^{* * *} \\
(1.744)\end{array}$ & $\begin{array}{c}2.694 \\
(3.012)\end{array}$ & $\begin{array}{l}4.420^{* *} \\
(1.774)\end{array}$ & $\begin{array}{c}3.278 \\
(3.245)\end{array}$ & $\begin{array}{c}4.589 * * * \\
(1.731)\end{array}$ \\
\hline Wholesale, Retail and Transportation $_{d t}$ & $\begin{array}{l}6.118^{* *} \\
(3.052)\end{array}$ & $\begin{array}{l}-1.701 \\
(1.485)\end{array}$ & $\begin{array}{l}5.883^{*} \\
(3.071)\end{array}$ & $\begin{array}{l}-2.315 \\
(1.451)\end{array}$ & $\begin{array}{l}6.096^{* *} \\
(2.986)\end{array}$ & $\begin{array}{c}-1.62 \\
(1.512)\end{array}$ & $\begin{array}{l}5.134 * \\
(3.026)\end{array}$ & $\begin{array}{l}-1.505 \\
(1.490)\end{array}$ & $\begin{array}{l}6.329 * * \\
(3.146)\end{array}$ & $\begin{array}{l}-1.017 \\
(1.436)\end{array}$ \\
\hline Urban $_{d t}$ & $\begin{array}{l}-0.0237 \\
(0.218)\end{array}$ & $\begin{array}{c}0.215 \\
(0.164)\end{array}$ & $\begin{array}{l}-0.0153 \\
(0.218)\end{array}$ & $\begin{array}{c}0.247 \\
(0.163)\end{array}$ & $\begin{array}{l}-0.0639 \\
(0.219)\end{array}$ & $\begin{array}{c}0.139 \\
(0.166)\end{array}$ & $\begin{array}{c}-0.15 \\
(0.225)\end{array}$ & $\begin{array}{c}0.163 \\
(0.163)\end{array}$ & $\begin{array}{l}-0.188 \\
(0.235)\end{array}$ & $\begin{array}{l}0.285^{*} \\
(0.163)\end{array}$ \\
\hline Foreign - born $d t$ & $\begin{array}{l}1.166^{* *} \\
(0.540)\end{array}$ & $\begin{array}{l}0.626^{* *} \\
(0.284)\end{array}$ & $\begin{array}{l}1.195^{* *} \\
(0.546)\end{array}$ & $\begin{array}{l}0.647^{* *} \\
(0.283)\end{array}$ & $\begin{array}{l}1.145^{* *} \\
(0.540)\end{array}$ & $\begin{array}{c}0.665^{* *} \\
(0.295)\end{array}$ & $\begin{array}{l}1.032 * \\
(0.547)\end{array}$ & $\begin{array}{c}0.602 * * \\
(0.289)\end{array}$ & $\begin{array}{l}1.288^{* *} \\
(0.557)\end{array}$ & $\begin{array}{l}0.528 * \\
(0.282)\end{array}$ \\
\hline African - American $d t$ & $\begin{array}{c}0.548 \\
(0.403)\end{array}$ & $\begin{array}{c}-0.24 \\
(0.184)\end{array}$ & $\begin{array}{c}0.543 \\
(0.402)\end{array}$ & $\begin{array}{l}-0.275 \\
(0.182)\end{array}$ & $\begin{array}{c}0.543 \\
(0.402)\end{array}$ & $\begin{array}{r}-0.0855 \\
(0.186)\end{array}$ & $\begin{array}{c}0.624 \\
(0.417)\end{array}$ & $\begin{array}{l}-0.104 \\
(0.185)\end{array}$ & $\begin{array}{l}0.720^{*} \\
(0.419)\end{array}$ & $\begin{array}{l}-0.147 \\
(0.186)\end{array}$ \\
\hline Age - representative $d t$ & $\begin{array}{c}0.00482 \\
(0.004)\end{array}$ & $\begin{array}{c}0.0000273 \\
(0.002)\end{array}$ & $\begin{array}{c}0.00531 \\
(0.004)\end{array}$ & $\begin{array}{c}0.000638 \\
(0.002)\end{array}$ & $\begin{array}{c}0.00392 \\
(0.004)\end{array}$ & $\begin{array}{c}0.000553 \\
(0.002)\end{array}$ & $\begin{array}{c}0.00223 \\
(0.004)\end{array}$ & $\begin{array}{c}0.000113 \\
(0.002)\end{array}$ & $\begin{array}{c}0.00253 \\
(0.004)\end{array}$ & $\begin{array}{c}-0.000238 \\
(0.002)\end{array}$ \\
\hline Gender - representative ${ }_{d t}$ & $\begin{array}{l}0.0796 \\
(0.114)\end{array}$ & $\begin{array}{l}-0.0188 \\
(0.067)\end{array}$ & $\begin{array}{l}0.0913 \\
(0.114)\end{array}$ & $\begin{array}{c}0.00904 \\
(0.068)\end{array}$ & $\begin{array}{l}0.0527 \\
(0.116)\end{array}$ & $\begin{array}{l}0.0136 \\
(0.068)\end{array}$ & $\begin{array}{c}0.052 \\
(0.117)\end{array}$ & $\begin{array}{l}0.0101 \\
(0.069)\end{array}$ & $\begin{array}{l}0.0491 \\
(0.116)\end{array}$ & $\begin{array}{l}0.0334 \\
(0.064)\end{array}$ \\
\hline Democrat $_{d t}$ & $\begin{array}{c}0.106 \\
(0.087)\end{array}$ & $\begin{array}{c}-0.334 * * * \\
(0.048)\end{array}$ & $\begin{array}{l}0.0934 \\
(0.090)\end{array}$ & $\begin{array}{c}-0.351^{* * *} \\
(0.048)\end{array}$ & & & & & $\begin{array}{l}0.0771 \\
(0.100)\end{array}$ & $\begin{array}{c}-0.293^{* * *} \\
(0.054)\end{array}$ \\
\hline Educ - representative - ivy ${ }_{d t}$ & & & $\begin{array}{l}0.0766 \\
(0.117)\end{array}$ & $\begin{array}{c}0.179 * * * \\
(0.057)\end{array}$ & & & & & & \\
\hline Normalized DW - nominate score $_{d t}$ & & & & & $\begin{array}{l}0.199 * \\
(0.113)\end{array}$ & $\begin{array}{c}-0.335 * * * \\
(0.065)\end{array}$ & & & & \\
\hline ADA score ${ }_{d t}$ & & & & & & & $\begin{array}{c}0.00235 \\
(0.001)\end{array}$ & $\begin{array}{c}-0.00488^{* * *} \\
(0.001)\end{array}$ & & \\
\hline PacLabor $_{d t}$ & & & & & & & & & $\begin{array}{c}0.171 \\
(0.129)\end{array}$ & $\begin{array}{c}-0.103^{* *} \\
(0.045)\end{array}$ \\
\hline PacCorporate $_{d t}$ & & & & & & & & & $\begin{array}{l}0.0476 \\
(0.087)\end{array}$ & $\begin{array}{c}0.212^{* * *} \\
(0.038)\end{array}$ \\
\hline
\end{tabular}

\begin{tabular}{lllll}
\hline State*year fixed effect & YES & YES & YES & YES \\
Other sectors & YES & YES & YES & YES \\
\hline Observations & 1404 & 1404 & 1404 & 1376 \\
R-squared & 0.425 & 0.43 & 0.41 & 1375 \\
\hline \hline
\end{tabular}

The dependent variable is the dummy Vote $d t$ which is coded as 1 if the representative of district d at time t votes on a bill in favor of trade or migration, 0 otherwise. Mean Opinion $_{d t}$ is the average opinion of district $\mathrm{d}$ at time $\mathrm{t}$ and ranges between 0 and 1 (the closer to 1 the more in favor of trade liberalization or pro-immigration). Congruence $_{d t}$ measures the match between newspaper markets and U.S. congressional districts. Interaction ${ }_{d t}$ measures the interaction between Mean Opinion ${ }_{d t}$ and Congruence $_{d t}$. SkillRatio $_{d t}$ measures the percentage of the population over 25 with at least a bachelor degree. Unemployment $d t$ is the share of unemployed individuals in the total labor force. Log mean family income ${ }_{d t}$ measures the logarithm of mean family income within a district. Farmer $d t$ measures the share of farm workers in the total labor force. Wholesale, Retail and Transportation ${ }_{d t}$ is the share of people employed in the wholesale, retail trade and transportation sectors in the total labor force. Urban $d t$ is a measure of the share of population living in urban areas. Foreign - born ${ }_{d t}$ is the share of foreign-born individuals in the total population. African - American $_{d t}$ is the share of African-American individuals in the total population. Age - representative $d t$ is the age of congressperson of district i at the beginning of current congress. Gender - representative $d t$ is coded as 1 for female congresspersons, 0 otherwise. Democrat ${ }_{d t}$ is coded as 1 if the representative of the district belongs to the Democratic Party. Educ - representative - ivy id is a dummy which takes value 1 if representative of district d graduated at an Ivy League school. Normalized $D W$ - nominate score ${ }_{d t}$ measures the ideological orientation of representative of district $\mathrm{d}$ (the higher the score the more liberal the politician). ADA score $_{d t}$ is another measure of politician ideology (the higher the score the more liberal the politician). PacLabor $d t$ and PacCorporate $d t$ are dummies which take value 1 if the politician of district $d$ in year $t$ has received labor/corporate contributions at or above the eightieth percentile of all labor/corporate contributions in that year. 


\begin{tabular}{|c|c|c|c|c|c|c|c|c|c|c|}
\hline & \multicolumn{2}{|c|}{ (1) } & \multicolumn{2}{|c|}{ 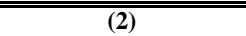 } & \multicolumn{2}{|c|}{ (3) } & \multicolumn{2}{|c|}{ (4) } & \multicolumn{2}{|c|}{ 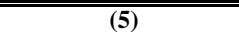 } \\
\hline & Migration & Trade & Migration & Trade & Migration & Trade & Migration & Trade & Migration & Trade \\
\hline Opinion $_{d t}$ & $\begin{array}{l}-1.006 \\
(0.731)\end{array}$ & $\begin{array}{c}-0.271 \\
(0.281)\end{array}$ & $\begin{array}{l}-1.134 \\
(0.763)\end{array}$ & $\begin{array}{c}-0.4 \\
(0.311)\end{array}$ & $\begin{array}{l}-1.342^{*} \\
(0.735)\end{array}$ & $\begin{array}{l}-0.472 \\
(0.314)\end{array}$ & $\begin{array}{c}-2.087 * * \\
(0.822)\end{array}$ & $\begin{array}{c}-0.51 \\
(0.322)\end{array}$ & $\begin{array}{c}-2.045^{* *} \\
(0.823)\end{array}$ & $\begin{array}{l}-0.186 \\
(0.351)\end{array}$ \\
\hline Congruence $_{d t}$ & $\begin{array}{c}-3.171^{* * *} \\
(1.132)\end{array}$ & $\begin{array}{l}-0.0713 \\
(0.462)\end{array}$ & $\begin{array}{c}-2.591 * * \\
(1.270)\end{array}$ & $\begin{array}{c}0.335 \\
(0.503)\end{array}$ & $\begin{array}{c}-2.902^{* *} \\
(1.350)\end{array}$ & $\begin{array}{c}-1.402 * * \\
(0.596)\end{array}$ & $\begin{array}{l}-1.993 \\
(1.403)\end{array}$ & $\begin{array}{c}-1.188 * \\
(0.634)\end{array}$ & $\begin{array}{l}-1.322 \\
(1.414)\end{array}$ & $\begin{array}{l}-1.081 \\
(0.659)\end{array}$ \\
\hline Interaction $_{d t}$ & $\begin{array}{c}6.572^{* * *} \\
(2.097)\end{array}$ & $\begin{array}{c}1.675^{*} \\
(0.936)\end{array}$ & $\begin{array}{c}6.530^{* * *} \\
(2.049)\end{array}$ & $\begin{array}{c}0.856 \\
(0.998)\end{array}$ & $\begin{array}{c}6.925^{* * *} \\
(2.072)\end{array}$ & $\begin{array}{c}0.916 \\
(0.998)\end{array}$ & $\begin{array}{c}7.965^{* * *} \\
(2.159)\end{array}$ & $\begin{array}{c}0.93 \\
(1.013)\end{array}$ & $\begin{array}{c}7.634^{* * *} \\
(2.143)\end{array}$ & $\begin{array}{l}-0.196 \\
(1.123)\end{array}$ \\
\hline SkillRatio $_{d t}$ & & & $\begin{array}{l}4.775^{*} \\
(2.777)\end{array}$ & $\begin{array}{c}0.445 \\
(1.411)\end{array}$ & $\begin{array}{l}9.959 * \\
(5.870)\end{array}$ & $\begin{array}{c}7.495^{* * *} \\
(2.526)\end{array}$ & $\begin{array}{c}13.57 * * \\
(6.114)\end{array}$ & $\begin{array}{c}7.581^{* * *} \\
(2.470)\end{array}$ & $\begin{array}{l}14.12 * * \\
(6.681)\end{array}$ & $\begin{array}{c}2.16 \\
(2.672)\end{array}$ \\
\hline Unemployment $_{d t}$ & & & $\begin{array}{c}12.04 \\
(8.354)\end{array}$ & $\begin{array}{c}-13.45^{* * *} \\
(4.166)\end{array}$ & $\begin{array}{c}22.64^{*} \\
(11.590)\end{array}$ & $\begin{array}{c}-15.98 * * * \\
(5.830)\end{array}$ & $\begin{array}{l}24.42^{* *} \\
(11.460)\end{array}$ & $\begin{array}{c}-14.69 * * \\
(6.194)\end{array}$ & $\begin{array}{l}28.27 * * \\
(11.240)\end{array}$ & $\begin{array}{c}-13.91^{* *} \\
(6.379)\end{array}$ \\
\hline Log mean family income $d t$ & & & $\begin{array}{l}-0.741 \\
(1.244)\end{array}$ & $\begin{array}{c}0.559 \\
(0.638)\end{array}$ & $\begin{array}{c}-2.197 \\
(1.731)\end{array}$ & $\begin{array}{l}-1.034 \\
(0.714)\end{array}$ & $\begin{array}{l}-2.168 \\
(1.754)\end{array}$ & $\begin{array}{l}-0.937 \\
(0.740)\end{array}$ & $\begin{array}{l}-1.511 \\
(1.813)\end{array}$ & $\begin{array}{c}-0.97 \\
(0.730)\end{array}$ \\
\hline Farmer $_{d t}$ & & & & & $\begin{array}{c}11.19 \\
(11.990)\end{array}$ & $\begin{array}{c}26.00 * * * \\
(7.075)\end{array}$ & $\begin{array}{c}23.84^{*} \\
(14.060)\end{array}$ & $\begin{array}{c}25.06^{* * * *} \\
(7.517)\end{array}$ & $\begin{array}{l}28.77 * * \\
(14.260)\end{array}$ & $\begin{array}{c}21.91^{* * *} \\
(8.003)\end{array}$ \\
\hline Construction $_{d t}$ & & & & & $\begin{array}{c}8.642 \\
(15.170)\end{array}$ & $\begin{array}{l}13.73^{*} \\
(7.380)\end{array}$ & $\begin{array}{c}25.77 \\
(17.010)\end{array}$ & $\begin{array}{l}15.27 * * \\
(7.557)\end{array}$ & $\begin{array}{c}32.91^{*} \\
(17.330)\end{array}$ & $\begin{array}{l}-3.688 \\
(8.652)\end{array}$ \\
\hline Manufacturing $_{d t}$ & & & & & $\begin{array}{c}6.28 \\
(9.380)\end{array}$ & $\begin{array}{c}3.823 \\
(4.069)\end{array}$ & $\begin{array}{c}14.48 \\
(9.647)\end{array}$ & $\begin{array}{c}4.127 \\
(4.082)\end{array}$ & $\begin{array}{l}17.40^{*} \\
(9.962)\end{array}$ & $\begin{array}{c}1.197 \\
(4.380)\end{array}$ \\
\hline Wholesale, Retail and Transportation $_{d t}$ & & & & & $\begin{array}{c}16.34 \\
(11.390)\end{array}$ & $\begin{array}{c}0.947 \\
(5.725)\end{array}$ & $\begin{array}{l}31.28^{* *} \\
(13.130)\end{array}$ & $\begin{array}{c}0.154 \\
(5.703)\end{array}$ & $\begin{array}{c}38.10^{* * *} \\
(13.350)\end{array}$ & $\begin{array}{l}-4.049 \\
(5.877)\end{array}$ \\
\hline Finance $_{d t}$ & & & & & $\begin{array}{c}6.996 \\
(13.980)\end{array}$ & $\begin{array}{c}10.42 \\
(6.400)\end{array}$ & $\begin{array}{c}9.659 \\
(14.640)\end{array}$ & $\begin{array}{c}10.2 \\
(6.346)\end{array}$ & $\begin{array}{c}15.93 \\
(14.480)\end{array}$ & $\begin{array}{c}5.729 \\
(6.754)\end{array}$ \\
\hline Professionals $_{d t}$ & & & & & $\begin{array}{c}6.846 \\
(19.140)\end{array}$ & $\begin{array}{l}-10.93 \\
(7.917)\end{array}$ & $\begin{array}{c}5.337 \\
(20.300)\end{array}$ & $\begin{array}{l}-12.83 * \\
(7.495)\end{array}$ & $\begin{array}{c}7.288 \\
(21.200)\end{array}$ & $\begin{array}{l}-7.512 \\
(7.742)\end{array}$ \\
\hline Education and Health $_{d t}$ & & & & & $\begin{array}{c}-1.256 \\
(9.592)\end{array}$ & $\begin{array}{c}0.845 \\
(4.663)\end{array}$ & $\begin{array}{c}3.432 \\
(9.201)\end{array}$ & $\begin{array}{c}2.445 \\
(4.866)\end{array}$ & $\begin{array}{c}3.833 \\
(9.293)\end{array}$ & $\begin{array}{c}1.299 \\
(5.198)\end{array}$ \\
\hline Entertainment Services $_{d t}$ & & & & & $\begin{array}{c}1.19 \\
(18.620)\end{array}$ & $\begin{array}{c}6.959 \\
(6.379)\end{array}$ & $\begin{array}{c}18.33 \\
(18.970)\end{array}$ & $\begin{array}{c}6.626 \\
(6.372)\end{array}$ & $\begin{array}{c}15.84 \\
(21.890)\end{array}$ & $\begin{array}{c}4.525 \\
(6.567)\end{array}$ \\
\hline Public Administration $_{d t}$ & & & & & $\begin{array}{c}-0.396 \\
(10.120)\end{array}$ & $\begin{array}{l}9.887^{*} \\
(5.238)\end{array}$ & $\begin{array}{c}8.925 \\
(10.530)\end{array}$ & $\begin{array}{l}12.50^{* *} \\
(5.612)\end{array}$ & $\begin{array}{c}10.82 \\
(11.150)\end{array}$ & $\begin{array}{c}9.457 \\
(5.974)\end{array}$ \\
\hline Urban $_{d t}$ & & & & & & & $\begin{array}{c}0.415 \\
(0.805)\end{array}$ & $\begin{array}{c}0.191 \\
(0.509)\end{array}$ & $\begin{array}{c}-0.0289 \\
(0.850)\end{array}$ & $\begin{array}{c}1.133^{* *} \\
(0.545)\end{array}$ \\
\hline Foreign - born $_{d t}$ & & & & & & & $\begin{array}{c}6.384 * * * \\
(2.342)\end{array}$ & $\begin{array}{c}1.498 \\
(0.934)\end{array}$ & $\begin{array}{c}5.350 * * * \\
(2.072)\end{array}$ & $\begin{array}{l}1.637 * \\
(0.930)\end{array}$ \\
\hline African - American $_{d t}$ & & & & & & & $\begin{array}{c}2.194 \\
(1.365)\end{array}$ & $\begin{array}{l}-0.483 \\
(0.648)\end{array}$ & $\begin{array}{l}2.643^{*} \\
(1.389)\end{array}$ & $\begin{array}{l}-1.131 \\
(0.690)\end{array}$ \\
\hline Age - representative ${ }_{d t}$ & & & & & & & & & $\begin{array}{l}0.0172 \\
(0.012)\end{array}$ & $\begin{array}{c}0.00203 \\
(0.006)\end{array}$ \\
\hline Gender - representative $_{d t}$ & & & & & & & & & $\begin{array}{c}0.459 \\
(0.374)\end{array}$ & $\begin{array}{l}-0.153 \\
(0.222)\end{array}$ \\
\hline Democrat $_{d t}$ & & & & & & & & & $\begin{array}{c}0.678 * * \\
(0.333)\end{array}$ & $\begin{array}{c}-1.382 * * * \\
(0.196)\end{array}$ \\
\hline
\end{tabular}

\begin{tabular}{lccccc}
\hline State*year fixed effect & YES & YES & YES & YES & YES \\
\hline Observations & 1404 & 1404 & 1404 & 1404 \\
\hline
\end{tabular}

The dependent variable is the dummy Vote $d t$ which is coded as 1 if the representative of district d at time t votes on a bill in favor of trade or migration, 0 otherwise.

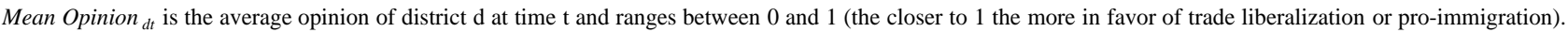
Congruence $_{d t}$ measures the match between newspaper markets and U.S. congressional districts. Interaction ${ }_{d t}$ measures the interaction between Mean Opinion ${ }_{d t}$ and Congruence $_{d t}$. SkillRatio $_{d t}$ measures the percentage of the population over 25 with at least a bachelor degree. Unemployment $d t$ is the share of unemployed individuals in the total labor force. Log mean family income ${ }_{d t}$ measures the logarithm of mean family income within a district in dollars. Farmer $d t$ measures the share

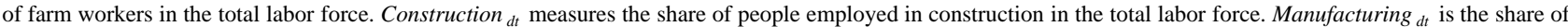
people employed in the manufacturing industry in the total laborforce. Wholesale, Retail and Transportation ${ }_{d t}$ is the share of people employed in the wholesale, retail trade and transportation sectors in the total labor force. Finance ${ }_{d t}$ measures the share of people employed in the financial, insurance and real estate industry in the total labor force. Professionals $d t$ measures the share of people employed in professional, scientific, management, administrative, and waste management services in the total labor force. Education and Health ${ }_{d t}$ is the share of people employed in the educational sector and in the health and social services sector in the total labor force. Entertainment Services ${ }_{d t}$ measures the share of people employed in the entertainment, recreation, accommodation and food services industries in the total labor force. Public Administration $_{d t}$ measures the share of individuals employed in public administration in the total labor force. Urban ${ }_{d t}$ is a measure of the share of population living in urban areas. Foreign - born ${ }_{d t}$ is the share of foreign-born individuals in the total population. African - American ${ }_{d t}$ is the share of AfricanAmerican individuals in the total population. Age - representative $d t$ is the age of congressperson of district i at the beginning of current congress. Gender representative $_{d t}$ is coded as 1 for female congress persons, 0 otherwise. Democrat $d t$ is coded as 1 if the representative of the district belongs to the Democratic Party. 